\title{
APP Regulates Microglial Phenotype in a Mouse Model of Alzheimer's Disease
}

\author{
@i Gunjan D. Manocha, ${ }^{1}$ Angela M. Floden, ${ }^{1}$ @Keiko Rausch, ${ }^{1}$ ○Joshua A. Kulas, ${ }^{1}$ Brett A. McGregor, ${ }^{1}$

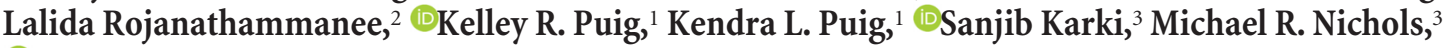 \\ D. Diane C. Darland, ${ }^{4}$ James E. Porter, ${ }^{1}$ and Colin K. Combs ${ }^{1}$ \\ ${ }^{1}$ Department of Biomedical Sciences, University of North Dakota School of Medicine and Health Sciences, Grand Forks, North Dakota 58203, ${ }^{2}$ Institute of \\ Science, Suranaree University of Technology, Nakhon Ratchasima, 30000 Thailand, ${ }^{3}$ Department of Chemistry and Biochemistry, University of Missouri-St. \\ Louis, St. Louis, Missouri 63121-4400, and ${ }^{4}$ Department of Biology, University of North Dakota, Grand Forks, North Dakota 58202
}

Prior work suggests that amyloid precursor protein (APP) can function as a proinflammatory receptor on immune cells, such as monocytes and microglia. Therefore, we hypothesized that APP serves this function in microglia during Alzheimer's disease. Although fibrillar amyloid $\beta(\mathrm{A} \beta)$-stimulated cytokine secretion from both wild-type and APP knock-out ( $\mathrm{mAPP}^{-1-}$ ) microglial cultures, oligomeric $\mathrm{A} \beta$ was unable to stimulate increased secretion from $\mathrm{mAPP}^{-1-}$ cells. This was consistent with an ability of oligomeric A $\beta$ to bind APP. Similarly, intracerebroventricular infusions of oligomeric $\mathrm{A} \beta$ produced less microgliosis in $\mathrm{mAPP}^{-1-}$ mice compared with wild-type mice. The $\mathrm{mAPP}^{-1-}$ mice crossed to an APP/PS1 transgenic mouse line demonstrated reduced microgliosis and cytokine levels and improved memory compared with wild-type mice despite robust fibrillar $\mathrm{A} \beta$ plaque deposition. These data define a novel function for microglial APP in regulating their ability to acquire a proinflammatory phenotype during disease.

Key words: Alzheimer's disease; amyloid $\beta$ oligomers; amyloid precursor protein; microglia; neuroinflammation

Significance Statement

A hallmark of Alzheimer's disease (AD) brains is the accumulation of amyloid $\beta(\mathrm{A} \beta)$ peptide within plaques robustly invested with reactive microglia. This supports the notion that $\mathrm{A} \beta$ stimulation of microglial activation is one source of brain inflammatory changes during disease. $A \beta$ is a cleavage product of the ubiquitously expressed amyloid precursor protein (APP) and is able to self-associate into a wide variety of differently sized and structurally distinct multimers. In this study, we demonstrate both in vitro and in vivo that nonfibrillar, oligomeric forms of $\mathrm{A} \beta$ are able to interact with the parent APP protein to stimulate microglial activation. This provides a mechanism by which metabolism of APP results in possible autocrine or paracrine A $\beta$ production to drive the microgliosis associated with $\mathrm{AD}$ brains.

\section{Introduction}

Amyloid precursor protein (APP) is a type I integral membrane protein that undergoes proteolysis via amyloidogenic or nonamyloidogenic pathways (Esch et al., 1990; Shoji et al., 1992; Haass and Selkoe, 1993; Haass et al., 1993; Jarrett et al., 1993).

Received Dec. 31, 2015; revised May 20, 2016; accepted June 24, 2016.

Author contributions: G.D.M., J.A.K., B.A.M., L.R., K.L.P., M.R.N., D.C.D., J.E.P., and C.K.C. designed research; G.D.M., A.M.F., K.R., J.A.K., B.A.M., L.R., K.R.P., K.L.P., S.K., M.R.N., and C.K.C. performed research; G.D.M., A.M.F., K.R., J.A.K., B.A.M., L.R., K.R.P., K.L.P., S.K., M.R.N., D.C.D., J.E.P., and C.K.C. analyzed data; G.D.M., A.M.F., K.L.P., M.R.N., D.C.D., J.E.P., and C.K.C. wrote the paper.

This work was supported in part by National Institutes of Health Grants NIH 1R01AG026330 and NIH 1R01AG042819 (to C.K.C.)

The authors declare no competing financial interests.

Correspondence should be addressed to Colin K. Combs, Department of Biomedical Sciences, University of North Dakota, School of Medicine and Health Sciences, 504 Hamline Street, Room 118, Grand Forks, ND 58203. E-mail: colin.combs@med.und.edu.

DOI:10.1523/JNEUROSCI.4654-15.2016

Copyright $\odot 2016$ the authors $\quad 0270-6474 / 16 / 368471-16 \$ 15.00 / 0$
Amyloidogenic processing of APP leads to production of amyloid $\beta(\mathrm{A} \beta)$ peptide, which can undergo self-aggregation, particularly in the brains of Alzheimer's disease (AD) patients (Glenner and Wong, 1984; Masters et al., 1985). Although much interest focuses on the production and consequences of $\mathrm{A} \beta$ peptide, it is likely that APP has a broader role in both normal and disease conditions than simply being the parent protein of $\mathrm{A} \beta$ peptide.

APP is expressed in numerous tissues apart from the brain. including the spleen, liver, skin, intestine, kidney, adipose tissue, heart, muscle, and thymus (Selkoe et al., 1988; Joachim et al., 1989; Yamada et al., 1989; Sandbrink et al., 1994; Akaaboune et al., 2000; Herzog et al., 2004; Galloway et al., 2007; Lee et al., 2008). We and others have also demonstrated that APP is expressed in immune cells, where it has a role in regulating cellular phenotype (Mönning et al., 1992; Bullido et al., 1996; Sondag and Combs, 2004; Vehmas et al., 2004; Carrano and Das, 2015). For instance, expression on monocytic lineage cells modulates their 
ability to interact with extracellular matrix and mediates various cell-cell interactions (Small et al., 1992; Beher et al., 1996; Soba et al., 2005). The N-terminal crystalline structure of APP is reminiscent of a cell-surface receptor with many putative ligands already identified (Rossjohn et al., 1999) and the C terminus contains a well defined YENPTY cytoplasmic signaling motif (Borg et al., 1996). In addition, APP levels increase in both microglia and macrophages in a reactive, stimulatory environment (Bauer et al., 1991) and direct stimulation of APP with agonist antibody leads to robust activation of microglia/monocytes (Sondag and Combs, 2004, 2010; Austin et al., 2009). Collectively, these data suggest that APP serves as a cell-surface receptor regulating microglial activation.

One putative ligand mediating APP-dependent activation of these cells is the A $\beta$ peptide itself (Chung et al., 1999; Lorenzo et al., 2000; Wagner et al., 2000; Van Nostrand et al., 2002; Lu et al., 2003). Numerous studies have documented an ability of A $\beta$ peptide, in a range of multimeric states, to stimulate microglia to acquire a reactive phenotype (Combs et al., 1999, 2000, 2001a,b; Walsh et al., 2002; Sondag et al., 2009; Dhawan and Combs, 2012; Dhawan et al., 2012). In fact, $A \beta$ plaque-associated reactive microgliosis is a characteristic change in both rodent models of $\mathrm{AD}$ and human cases (Perlmutter et al., 1990; Wisniewski et al., 1992; Combs et al., 1999). To test the hypothesis that APP has a role in regulating microglial response to $\mathrm{A} \beta$ peptide, we compared $\mathrm{A} \beta$ stimulation of wild-type (WT) versus APP knock-out $\left(\mathrm{mAPP}^{-1-}\right) \mathrm{mi}^{-}$ croglia in vitro and in vivo following intracerebroventricular infusion. In addition, we compared microgliosis, cytokine levels, behavior, and plaque deposition in vivo in an APP/PS1 mouse model of $\mathrm{AD}$ crossed to $\mathrm{mAPP}^{-1-}$ mice. Collectively, our findings demonstrate that APP expression is required for microglial activation, particularly in response to oligomeric forms of $A \beta$.

\section{Materials and Methods}

Animals. APP/PS1 transgenic mice [strain 005864 B6.Cg-Tg (APPswe, PSEN1dE9)85Dbo/Mmjax], APP knock-out mice ( $\mathrm{mAPP}^{-\prime-}$ ), and WT mice (C57BL/6) were obtained from the Jackson Laboratory. APP/PS1 express the Swedish mutation in APP and $\triangle \mathrm{E} 9$ mutation in the PS1 gene, resulting in expression of human APP and secretion of human A $\beta$. APP/ PS1 mice were bred with $\mathrm{mAPP}^{-1-}$ mice and the offspring were genotyped. Mice positive for the APP/PS1 transgenes were further bred with $\mathrm{mAPP}^{-1-}$ mice for multiple generations to knock down mouse APP completely. The APP/PS $1 \times \mathrm{mAPP}^{-1-}$ mice, therefore, express the transgenes but lack mouse APP. Males from all four strains of mice [C57BL/6 (WT), APP/PS1, $\mathrm{mAPP}^{-1-}$, and $\left.\mathrm{APP} / \mathrm{PS} 1 \times \mathrm{mAPP}^{-1-}\right]$ were collected at 10 months of age for behavioral, histochemical, and biochemical analyses and 6-7 months of age for mRNA analysis.

Animal use. All animal use was approved by the University of North Dakota Institutional Animal Care and Use Committee Protocols 1505-4 and 0712-1C. Mice were provided food and water ad libitum and housed in a $12 \mathrm{~h} \mathrm{light/dark} \mathrm{cycle.} \mathrm{The} \mathrm{investigation} \mathrm{conforms} \mathrm{to} \mathrm{the} \mathrm{National}$ Research Council of the National Academies Guide for the Care and Use of Laboratory Animals (eighth edition).

Antibodies and reagents. Anti-A $\beta$ clones $6 \mathrm{E} 10$ and $4 \mathrm{G} 8$ and rodentspecific anti-A $\beta$ antibody were purchased from Covance, while MOAB-2 was from Cayman Chemical. Anti-phosphotyrosine (4G10) antibody was obtained from EMD Millipore. The horseradish peroxidase-conjugated secondary antibodies were purchased from Santa Cruz Biotechnology. Mouse TNF- $\alpha$ ELISA kits were obtained from R\&D Systems, while mouse $\mathrm{A} \beta$ 1-40 and $\mathrm{A} \beta$ 1-42 ELISA kits were obtained from ThermoFisher Scientific. Elite Vectastain ABC avidin and biotin kits, biotinylated anti-rabbit, anti-mouse, and anti-rat antibodies, and the Vector VIP kits were from Vector Laboratories. Anti-CD68 was obtained from Serotec. Anti-PSD95 antibody was purchased from Cell Signaling Technology. Anti-APP antibody was purchased from Invitrogen. Synaptophysin and $\beta$ III tubulin antibodies were purchased from Millipore
Bioscience Research Reagents. Anti-Iba-1 antibody was from Wako Chemicals. Anti-APP (Y188), TNF- $\alpha$, and CD11b antibodies were purchased from Abcam. A mixture of three N-terminal APP antibodies obtained from EMD Millipore (22C11 clone and N-terminus anti-APP rabbit polyclonal antibody) and Abcam (rabbit polyclonal antibody to APP) was used for the binding assay. The human APP plasmid (pCAX APP 695) was a gift from Dennis Selkoe and Tracy Young-Pearse (Addgene plasmid \#30137; Young-Pearse et al., 2007) and the pCMV-RFP plasmid was a gift from Dr. Saobo Lei and Nicholas Cilz.

Preparation of peptides. A $\beta 1-42$ was purchased from Bachem or American Peptide for fibril and oligomer preparations, respectively. Fluorescein-labeled $\mathrm{A} \beta$ was purchased from rPeptide for FITC-labeled $\mathrm{A} \beta$ oligomer preparation. Oligomers were generated from a modification as described by Chromy et al. (2003). A $\beta 1-42$ peptide was dissolved in 1:1 acetonitrile/water, aliquoted, and dried. The aliquoted peptides were stored at $-20^{\circ} \mathrm{C}$ until use. For oligomer preparation, aliquoted peptide was dissolved in $50 \mu$ l of hexafluoroisopropanol and then diluted with $175 \mu$ l of sterile water and stirred at room temperature for $48 \mathrm{~h}$. The peptide was then spun at $14,000 \mathrm{rpm}$ for $10 \mathrm{~min}$ and the supernatant quantified using the method of Bradford (1976). For $A \beta$ fibril preparations, $A \beta 1-42$ peptide was dissolved in deionized water and incubated for a week at $37^{\circ} \mathrm{C}$.

Primary microglia and astrocyte cell culture. Microglia were derived as described previously (Floden et al., 2005) from the brains of postnatal day 0-3 mice. Meninges-free cortices were removed, trypsinized, and triturated in microglia media [DMEM/F12 media containing L-glutamine (Invitrogen) and 20\% heat-inactivated FBS] and placed in T-75 flasks. The media in the flasks was replaced after $24 \mathrm{~h}$ and partially after $7 \mathrm{~d}$ with fresh media. The cells were harvested on day 14. Flasks were shaken for $30 \mathrm{~min}$ on a reciprocal shaker to obtain microglial cells. Adherent astrocytes were harvested using a 1 mM EDTA solution.

Primary neuron culture. Neurons were cultured from cortices of embryonic day (E) 16 mice (C57BL/6). Meninges-free cortices were isolated, trypsinized, and plated onto $0.05 \mathrm{mg} / \mathrm{ml}$ poly-L-lysine-coated tissue culture wells $\left(260\right.$ cells $\left./ \mathrm{mm}^{2}\right)$ for $14 \mathrm{~d}$ in vitro before use. Neurons were grown in Neurobasal media with glutamine and B27 supplements (Life Technologies).

Human microglia culture. Human microglia cells were obtained from Sciencell and maintained in complete microglia media supplemented with microglia growth medium, penicillin/streptomycin, and fetal bovine serum on poly-L-lysine-coated cell culture plates.

GripTite 293 MSR cell line. For binding assays, GripTite 293 MSR cells (GripTite cells) were purchased from ThermoFisher Scientific and maintained in DMEM/F12 media supplemented with $20 \%$ heat-inactivated FBS and $1 \%$ Geneticin antibiotic.

THP-1 cell APP siRNA knockdown. Human monocytic THP-1 cells were purchased from ATCC and grown as in our prior work (Sondag and Combs, 2004). APP siRNA knockdown was also performed as previously described (Sondag and Combs, 2004). Briefly, THP-1 cells were transfected with APP siRNA $\left(2 \times 10^{6}\right.$ cells; $2 \mu \mathrm{g}$ of siRNA) using the appropriate Nucleofector program as described by the manufacturer (Amaxa). Cells were transfected with APP siRNA (siGene, SMARTpool Plus) obtained from Dharmacon and used $24 \mathrm{~h}$ after transfection or lysed to determine APP expression.

Cell stimulation. Microglia or THP-1 cells were placed in serum-free DMEM/F12 media for stimulations with $\mathrm{A} \beta$ oligomers or fibrils. Cells were stimulated with oligomers or fibrils for $5 \mathrm{~min}$ or $24 \mathrm{~h}$ and harvested for Western blotting analyses or ELISA, respectively. For ELISA analysis, cells were stimulated in 96 -well plates $(20,000$ cells/well, $75 \mu \mathrm{l}$ of serumfree DMEM/F12) for $24 \mathrm{~h}$ with 8 replicates per condition repeated five independent times. Stimulation experiments for Western blot analyses were performed for $5 \mathrm{~min}$. After stimulation, cells were lysed in RIPA buffer (20 mм Tris, pH 7.4, $150 \mathrm{~mm} \mathrm{NaCl}, 1$ mm Na3VO $, 10 \mathrm{~mm} \mathrm{NaF}, 1$ mM EDTA, 1 mM EGTA, $0.2 \mathrm{~mm}$ phenylmethylsulfonyl fluoride, $1 \%$ Triton X-100, $0.1 \%$ SDS, and $0.5 \%$ deoxycholate) and quantified from five independent experiments.

Western blot analysis of cell lysates. Lysates were diluted in sample buffer and separated via 10\% SDS-PAGE, transferred to polyvinylidene difluoride membranes, and Western blotted using anti-p-Tyr (4G10), 
anti-APP (Y188), and anti-A $\beta$ (6E10) antibodies using anti-ERK-2, $\alpha$-tubulin, and GAPDH as the loading controls and enhanced chemiluminescence for detection (GE Healthcare). Optical densities (O.D.s) from visualized Western blots was normalized to their respective loading controls wherever necessary and averaged from three to five independent experiments.

ELISA from microglia cultures. To assess the level of the proinflammatory cytokine TNF- $\alpha$ secreted after $24 \mathrm{~h}$ stimulation of microglia with $\mathrm{A} \beta$ oligomers or fibrils, the media from the cells were collected and analyzed using a commercially available ELISA kit (R\&D Systems) according to the manufacturer's protocol.

Intracerebroventricular infusion of A $\beta 1-42$ oligomers. WT (C57BL/6) mice and $\mathrm{mAPP}^{-1-}$ mice were infused with $\mathrm{A} \beta$ oligomer intracerebroventricularly at 6 months of age as previously described (Dhawan et al., 2012). Briefly, mice were anesthetized with sodium pentobarbital (Nembutal, $70 \mathrm{mg} / \mathrm{kg}$ ). An Alzet (model 1004; $0.25 \mu \mathrm{l} / \mathrm{h}$ delivery rate) osmotic pump was placed in the subscapular region with a cannula (brain infusion kit, Alzet) stereotaxically placed into the right lateral cerebral ventricle at coordinates $-1.0 \mathrm{~mm}$ mediolateral and $-0.5 \mathrm{~mm}$ anterioposterior from bregma, $-1.5 \mathrm{~mm}$ dorsal-ventral from skull. The cannulas were connected to miniosmotic pumps (Alzet, model 1004) that were then placed subscapularly. The pumps delivered $\mathrm{A} \beta$ oligomer $(1.2 \mu \mathrm{g} / \mathrm{d}$ ) or vehicle ( $4 \mathrm{~mm}$ HEPES, $250 \mu \mathrm{g} / \mathrm{ml}$ human high-density lipoprotein; controls) for $14 \mathrm{~d}$. At the end of the infusion period, mice were transcardially perfused with $\mathrm{PBS}-\mathrm{CaCl}_{2}$ and brains rapidly dissected out. The right hemispheres were collected for cryosectioning and placed in $4 \%$ paraformaldehyde for $72 \mathrm{~h}$, replaced by two cycles of $30 \%$ sucrose for a period of 1 week. The left hemispheres were further dissected into frontal cortex, temporal cortex, hippocampus, and cerebellum. The tissue was flash frozen in liquid nitrogen and lysed in RIPA buffer for biochemical analysis.

Immunostaining mouse brains. The paraformaldehyde-fixed right hemispheres for $\mathrm{A} \beta$ oligomer-infused mice (WT and $\mathrm{mAPP}^{-1-}$ ), their respective controls, and 10-month-old mice from four genotypes (WT, $\mathrm{mAPP}^{-/-}, \mathrm{APP} / \mathrm{PS} 1$, and $\mathrm{APP} / \mathrm{PS} 1 \times \mathrm{mAPP}^{-/-}$) were cut using a freezing microtome. Briefly, paraformaldehyde-fixed tissue was embedded in a $15 \%$ gelatin (in $0.1 \mathrm{~m}$ phosphate buffer) matrix and immersed in a $4 \%$ paraformaldehyde solution for $2 \mathrm{~d}$ to harden the gelatin matrix. The blocks were then cryoprotected through three cycles of 30\% sucrose for 3-4 d each. The blocks were then flash frozen using dry-ice/isomethylpentane, and $40 \mu \mathrm{m}$ serial sections were cut using a freezing microtome. Serial sections (separated by a $240 \mu \mathrm{m}$ gap) were immunostained using anti-pTyr (4G10) and anti-A $\beta$ (4G8) antibodies at a dilution of 1:1000 or anti-CD68, anti-CD11b, and anti-Iba-1 antibodies at a dilution of 1:500 followed by incubation with biotinylated secondary antibodies (1:2000 dilution; Vector Laboratories) and avidin/biotin solution (Vector ABC kit). Immunoreactivity was visualized using Vector VIP as chromogen. The slides were dehydrated and coverslipped using VectaMount (Vector Laboratories) following a standard dehydrating procedure through a series of ethanol concentrations and Histo-Clear (National Diagnostics). Images were taken using an upright Leica DM1000 microscope and Leica DF320 digital camera system. Quantitation of immunostaining was performed as previously described (Dhawan et al., 2012). Briefly, optical densities from the temporal cortex and CA1 regions from the same serial sections were measured using Adobe Photoshop software (Adobe Systems). The values for each section were averaged ( 3 sections/brain, 6-7 brains per condition) and plotted.

Design-based stereological quantification of Iba-1-positive cells. Paraformaldehyde-imbedded sections from 10-month-old mice from four genotypes (WT, $\mathrm{mAPP}^{-/-}$, APP/PS1, and APP/PS1 $\times \mathrm{mAPP}^{-/-}$) were cut at $40 \mu \mathrm{m}$ intervals and immunolabeled for Iba-1. Sections from three different mice for each genotype of mice were assessed for Iba-1positive nuclei with the section interval set at $960 \mu \mathrm{m}$. Nonbiased quantification of Iba-1-positive nuclei was conducted using the optical fractionator method originally developed by West and colleagues (West and Gundersen, 1990) and adapted from previous studies with other neural populations (Sharma et al., 2012; Cain et al., 2014). Iba-1-positive cells in the temporal cortex layer were counted in every 24 th section using StereoInvestigator 11.06.2 (Microbrightfield) on an Olympus BX51WI equipped with a motorized $x, y$, and $z$ stage. In each animal, Iba-1positive cells were counted from 21 to 30 randomly and systematically selected frames in every serial section using the $40 \times$ objective. For cell counting, the contour of the temporal cortex with a pial surface buffer of $100 \mu \mathrm{m}$ was delineated with $2 \times$ magnification based on standard anatomical markers and the grid size set following subsampling optimization. In brief, the number and location of counting frames and the counting depth for that section were determined by entering parameters for the grid size $(500 \times 500 \mu \mathrm{m})$, the thickness of top guard zone $(2 \mu \mathrm{m})$, and the optical dissector height $(26 \mu \mathrm{m})$. The guard zones were set at 2 $\mu \mathrm{m}$ above and below the counting depth for each section with regional thickness and variation in section integrity taken into consideration and the maximum and minimum $z$ depth determined at each sampling location before counting. The optimal counting frame width $(250 \mu \mathrm{m})$ and height $(175 \mu \mathrm{m})$ were determined with an initial oversampling of a representative set of sections from control and treated samples. The cell bodies of the Iba-1-positive cells were counted if they were entirely within the $26 \mu \mathrm{m}$ depth of the counting frame and only at the $z$ depth at which the nucleus was in focus. The StereoInvestigator software calculated the total number of Iba-1-positive cells in the temporal cortex using the $3 \mathrm{D}$ optical fractionator formula designated: $\mathrm{N}=t / h \times 1 /$ ssf $\times 1 /$ asf $\times$ $1 / h s f \times \Sigma Q-$. For the calculations, $t / h$ is the section mounted thickness over the counting frame height; $s s f$ is the section sampling fraction; as $f$ is the area sampling fraction, which was calculated by dividing the area sampled with total area of the temporal cortex (in our tracings, the sum of temporal cortex areas sampled in every 24 th section); $h s f$ is the height sampling fraction, which was determined by dividing the height of the counting frame $(26 \mu \mathrm{m})$ by the section thickness determined for each sampling site (37-39 $\mu \mathrm{m}$ on average); and $\Sigma Q-$ denotes the total count of particles sampled for the entire temporal cortex. The sampling was optimized for maximal efficiency, with a final mean coefficient of error (West and Gundersen, 1990) Gundersen of $<10 \%$ for all sections sampled. One-way ANOVA (GraphPad Prism, 6.0c) was used to analyze positive nuclei and all data are presented as mean \pm SEM for $n=3$ samples.

Western blot analyses of mouse brains. Flash-frozen tissue from different brain regions of infusion experiment mice as well as age-matched four genotypes were lysed, sonicated in RIPA buffer, and quantitated using the Bradford method (Bradford, 1976). The lysates were resolved by SDS-PAGE and transferred to polyvinylidene difluoride membranes for Western blotting using anti-pTyr (4G10), anti-APP (Y188), anti-A $\beta$ (6E10), anti-A $\beta$ (rodent), anti-GFAP, anti-Iba-1, anti-PSD95, antisynaptophysin, anti-syntaxin, anti-TNF- $\alpha$, and anti-CD68 antibodies with $\alpha$-tubulin as the loading control. Antibody binding was detected using enhanced chemiluminescence for detection. Western blots were quantified using Adobe Photoshop software. Optical density (O.D.) of bands were normalized against their respective loading controls and averaged $( \pm$ SEM)

Thioflavin staining. Mouse brain sections from four genotype animals were stained with thioflavin $(0.1 \mathrm{~g} / 10 \mathrm{ml})$. To quench lipofuscin autofluorescence, the sections were then incubated in $0.1 \%$ Sudan black for 30 min, rinsed with PBS, and coverslipped using PBS/glycerol (1:1).

T maze. To assess the working memory of the mice, T-maze (Stoelting) analysis was performed on the four strains of mice as described by Wenk (2001). Mice were placed individually into the starting arm, and the door was raised to allow animals to walk down the stem and choose an arm. Once the mice entered an arm with all four feet, they were returned to the starting arm and the door was closed. After $30 \mathrm{~s}$, the door was opened and the mice were allowed to choose an arm again. The process was repeated for nine trials with a $30 \mathrm{~s}$ interval between each trial. The choice of arms was noted each time and the number of alternations between trials for each mouse was averaged and plotted.

Open-field test. The open-field (Stoelting) test was used to evaluate locomotor activity and anxiety of the mice. Mice were placed individually in the middle of an open-field apparatus placed inside of a larger opaque wooden box with the four corners of the arena designated as Q1, Q2, Q3, and Q4. Mice were allowed to explore the open field for $5 \mathrm{~min}$ while horizontal activity reflecting the range of motion was recorded. After each $5 \mathrm{~min}$ session, the open-field apparatus was cleaned and the next 
mouse was tested. Animal behavior was analyzed via ANY-maze software (Stoelting).

Light-dark box. Light-dark box (Stoelting) testing was also performed to assess anxiety in the mice. The light/dark box had two compartments separated by a wall with an open door between the two chambers. Each animal was initially placed in the light compartment and allowed to move freely in the apparatus for $5 \mathrm{~min}$. The movement was recorded and analyzed by ANY-maze software. After each trial, the chambers were cleaned and next mouse placed for testing.

Migration assay. Microglia $\left(1.0 \times 10^{6}\right)$ were plated into the serum-free DMEM/F12-containing upper chamber of a 24-well transwell insert (3 $\mu \mathrm{m}$, Corning) with the bottom chamber with or without $100 \mathrm{ng} / \mathrm{ml}$ mouse MIP-1 $\beta$ (R\&D Systems). Cells were allowed to migrate for $6 \mathrm{~h}$, then the transwell insert was removed and cells migrated through to the bottom of the well were counted and averaged ( \pm SEM).

Phagocytosis assay. Phagocytosis was quantified by measuring the uptake of Escherichia coli (K-12 strain) BioParticles fluorescein conjugate (Life Technologies). Briefly, FITC-E. coli BioParticles $(0.25 \mathrm{mg} / \mathrm{ml})$ were incubated with the microglia $\left(2.0 \times 10^{4} /\right.$ well $)$ in 96 -well plates for $6 \mathrm{~h}$. The media were removed and the cells were then rinsed with $0.25 \mathrm{mg} / \mathrm{ml}$ trypan blue in PBS to quench signal from extracellular BioParticles. Intracellular fluorescence was read (excitation, $480 \mathrm{~nm}$; emission, $520 \mathrm{~nm}$ ) via fluorescent plate reader (Bio-Tek).

Cell-proliferation assay. A 3[4,5-dimethylthiazol-2-yl]-2,5-diphenyltetrazolium bromide (MTT) reduction assay was performed to compare proliferation ability of microglia. For assessing proliferation, $2.0 \times$ $10^{4}$ microglia from each of the genotypes was plated on a 96-well plate for $24 \mathrm{~h}$ in the absence or presence of mitogen-enriched media containing $10 \% \mathrm{FBS} / 5 \% \mathrm{HS}$. The media were removed and $100 \mu \mathrm{g} / \mathrm{ml} 3$ MTT was added to culture for $4 \mathrm{~h}$ at $37^{\circ} \mathrm{C}$. Media were aspirated and the reduced formazan precipitate was dissolved in isopropanol and absorbances were read at $560 / 650 \mathrm{~nm}$ via plate reader.

ELISA-based $A \beta$ binding assay. Oligomeric and fibrillar $\mathrm{A} \beta$ were analyzed for binding ability to APP using a modified ELISA protocol. A high-binding 96-well plate (R\&D Systems) was coated with recombinant human APP (R\&D Systems) at a concentration of $1 \mu \mathrm{g} / \mathrm{ml}$ overnight at room temperature. The next day, wells were rinsed using ELISA wash buffer (R\&D Systems) and incubated with varying concentrations of oligomeric or fibrillar $\mathrm{A} \beta(50,100,250,500$, and 1000 $\mathrm{nm}$ ) for $24 \mathrm{~h}$ at $4^{\circ} \mathrm{C}$. Following $\mathrm{A} \beta$ incubation, the wells were rinsed and incubated with anti-A $\beta$-specific antibody (MOAB-2) for $2 \mathrm{~h}$ followed by incubation with biotinylated anti-mouse secondary antibody. This was followed by streptavidin-conjugated HRP antibody incubation and detection using ELISA substrate reagents (R\&D Systems). The plate was then read using a microplate reader (Biotek Instruments) at $450 / 550 \mathrm{~nm}$.

Fluorescein-labeled $A \beta$ binding assay. Oligomers prepared using FITC-labeled A $\beta$ (FITC-A $\beta$ o) were analyzed for binding to APP using APP-transfected GripTite 293 MSR cells. Briefly, GripTite cells were transiently transfected with an APP plasmid and mock transfected using an RFP-plasmid using Lipofectamine 3000 (ThermoFisher Scientific) as per the manufacturer's protocol. APP-transfected GripTite cells were 4\% paraformaldehyde fixed at $48 \mathrm{~h}$ after transfection and immunostained using anti-N-terminus APP antibody (EMD Millipore) in the absence of detergent to identify the expression of cell-surface APP protein. Briefly, fixed APP-transfected GripTite cells were blocked with PBS containing $5 \% \mathrm{BSA}$ and incubated with anti-N-terminus APP antibody overnight at $4^{\circ} \mathrm{C}$ followed by incubation with Alexa-488-tagged anti-rabbit secondary antibody (Invitrogen). The cells were also incubated with only secondary antibody to confirm positive immunoreactivity with the APP primary antibody. Immunoreactivity was visualized using a Leica DMI6000B inverted microscope and a Leica DFC350FX digital camera (Leica Microsystems). To identify the binding pattern of FITC-A $\beta$ o $48 \mathrm{~h}$ after transfection, GripTite cells were incubated with varying concentrations of FITC-A $\beta$ o. Following 15 min incubations, the cells were washed with DMEM/F12 media and fluorescence intensity was obtained by reading the plate using a microplate reader at an excitation at $490 \mathrm{~nm}$ and emission at $525 \mathrm{~nm}$. Cells were then fixed with $4 \%$ paraformaldehyde and counterstained with DAPI (4',6-diamidino-2-phenylindole, dihydro- chloride) and fluorescence intensity of DAPI read at 360/450 nm. Relative fluorescence units (RFUs) obtained for FITC-A $\beta$ o were normalized against RFUs for DAPI, averaged, and plotted ( \pm SEM). To understand the specific binding of FITC-A $\beta$ o to APP, APP-transfected GripTite cells were either left unblocked or blocked with a mix of $3 \mathrm{~N}$-terminal APP antibodies $(1 \mu \mathrm{g} / \mathrm{ml}$, each) for $30 \mathrm{~min}$. Cells were then incubated with FITC-A $\beta \mathrm{o}$ and the binding was determined as mentioned above. To further validate the binding of $\mathrm{A} \beta \mathrm{o}$ to $\mathrm{APP}$, a competition binding assay was performed using unlabeled A $\beta$ o. APP-transfected cells were incubated with increasing concentrations of unlabeled $A \beta$ o for $30 \mathrm{~min}$ and then competition binding was analyzed by treating the cells with 50 nм FITC-A $\beta$ o for 15 min. All RFU values were normalized against DAPI fluorescence intensity and presented as \pm SEM from three independent experiments. To calculate equilibrium dissociation constants for $\mathrm{A} \beta$ oligomers, nonlinear regression analysis was performed using GraphPad Prism version 6.05 for Windows (GraphPad Software, www.graphpad.com).

Dot blot. Oligomeric and fibrillar A $\beta$ ( $2 \mu$ g each $)$ were dot blotted onto polyvinylidene difluoride membranes and incubated with anti-A $\beta$ (MOAB-2) antibody. Antibody binding was detected using enhanced chemiluminescence for detection.

Tissue cytokine $m$ RNA real-time PCR and ELISA. Parietal cortices from 6 to 7 months of WT, APP/PS1, $\mathrm{mAPP}^{-1-}$, and APP/PS1 $\times \mathrm{mAPP}^{-1-}$ mice were lysed using Qiazol RNA lysis buffer and RNA was isolated using Qiagen RNeasy Lipid Tissue Kit (Qiagen) according to the manufacturer's protocol. For amplification of mRNA for cytokine markers (TNF- $\alpha$, IL-6, and IL-10), 150 ng of RNA was used as a template for performing real-time PCR using the iTaq Universal SYBR Green OneStep kit (Bio-Rad). Additionally, part of the parietal cortices were lysed in RIPA buffer and protein levels quantified using the BCA assay. The lysates were used to quantify TNF- $\alpha$ levels using a commercially available ELISA kit (R\&D Systems) according to the manufacturer's protocol. TNF- $\alpha$ concentrations (picograms per milliliter) were calculated per total protein level in the tissue lysate and plotted ( \pm SEM).

Statistical analysis. Data are presented as mean \pm SEM. Values statistically different from controls were determined using one-way ANOVA (or two-way ANOVA where required). The Tukey-Kramer multiplecomparisons post-test was used to determine $p$ values.

\section{Results}

A $\beta$ oligomer stimulation increased total protein phosphotyrosine levels and TNF- $\alpha$ secretion in microglia and THP-1 cells only when they expressed APP

To determine whether a particular form of $A \beta$ peptide might require APP expression for microglia stimulation, preparations of oligomeric and fibrillar $A \beta 1-42$ were prepared to stimulate primary murine microglia cultures or the human cell line THP-1. Oligomeric $\mathrm{A} \beta$ separated via SDS-PAGE into a range of molecular weights from $\sim 15$ to $55 \mathrm{kDa}$ (Fig. $1 A$ ). However, fibrillar $\mathrm{A} \beta$ remained SDS insoluble and unable to enter the resolving portion of the SDS gel (Fig. 1A). Both oligomeric and fibrillar A $\beta$ stimulated increased protein phosphotyrosine levels in primary THP-1 cultures and microglia (Fig. $1 B, C$ ). Fibrillar $\mathrm{A} \beta$ was still able to stimulate a significant increase in protein phosphotyrosine levels in APP-knockdown THP-1 cells or $\mathrm{mAPP}^{-/-}$microglia (Fig. $1 B, C)$. However, oligomeric $\mathrm{A} \beta$ had a completely attenuated ability to stimulate increased tyrosine phosphorylation in the absence of APP (Fig. 1B,C). To validate that the changes in stimulated tyrosine kinase-associated signaling corresponded to a change in secretory phenotype, media from WT and mAPP ${ }^{-1-}$ microglia were quantified for secreted TNF $\alpha$. As expected, both oligomeric and fibrillar $\mathrm{A} \beta$ stimulated increased TNF $\alpha$ secretion in WT microglia cultures (Fig. $1 D$ ). However, the ability of oligomeric but not fibrillar $\mathrm{A} \beta$ to stimulate increased TNF $\alpha$ secretion was completely attenuated in $\mathrm{mAPP}^{-1-}$ microglia (Fig. 1D). 
A

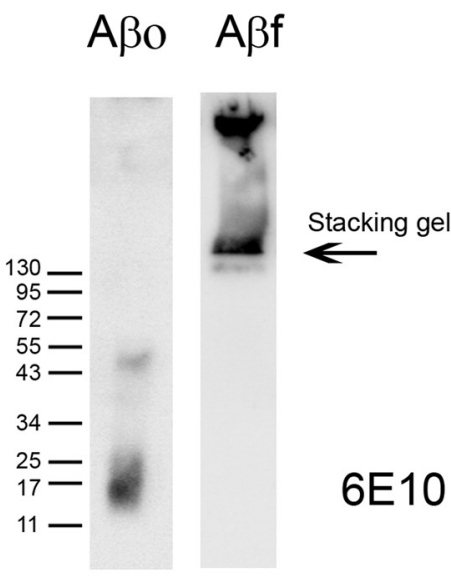

C
MAPP-/-

c $A \beta O A \beta f$

c $A \beta O A \beta f$
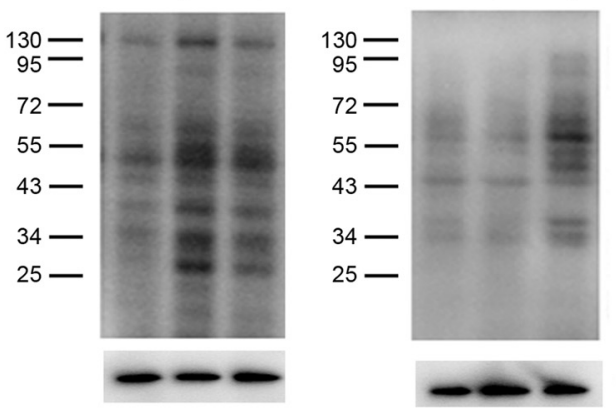

p-Tyr

$\alpha$-tubulin

B

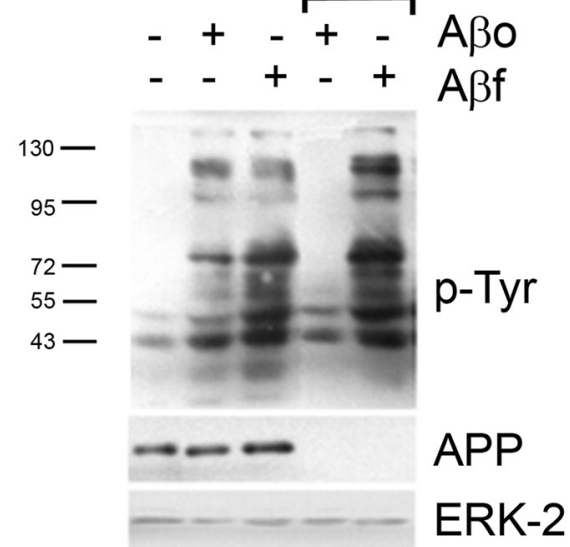

ERK-2

$\mathbb{N}$ WT

ImAPP-/-
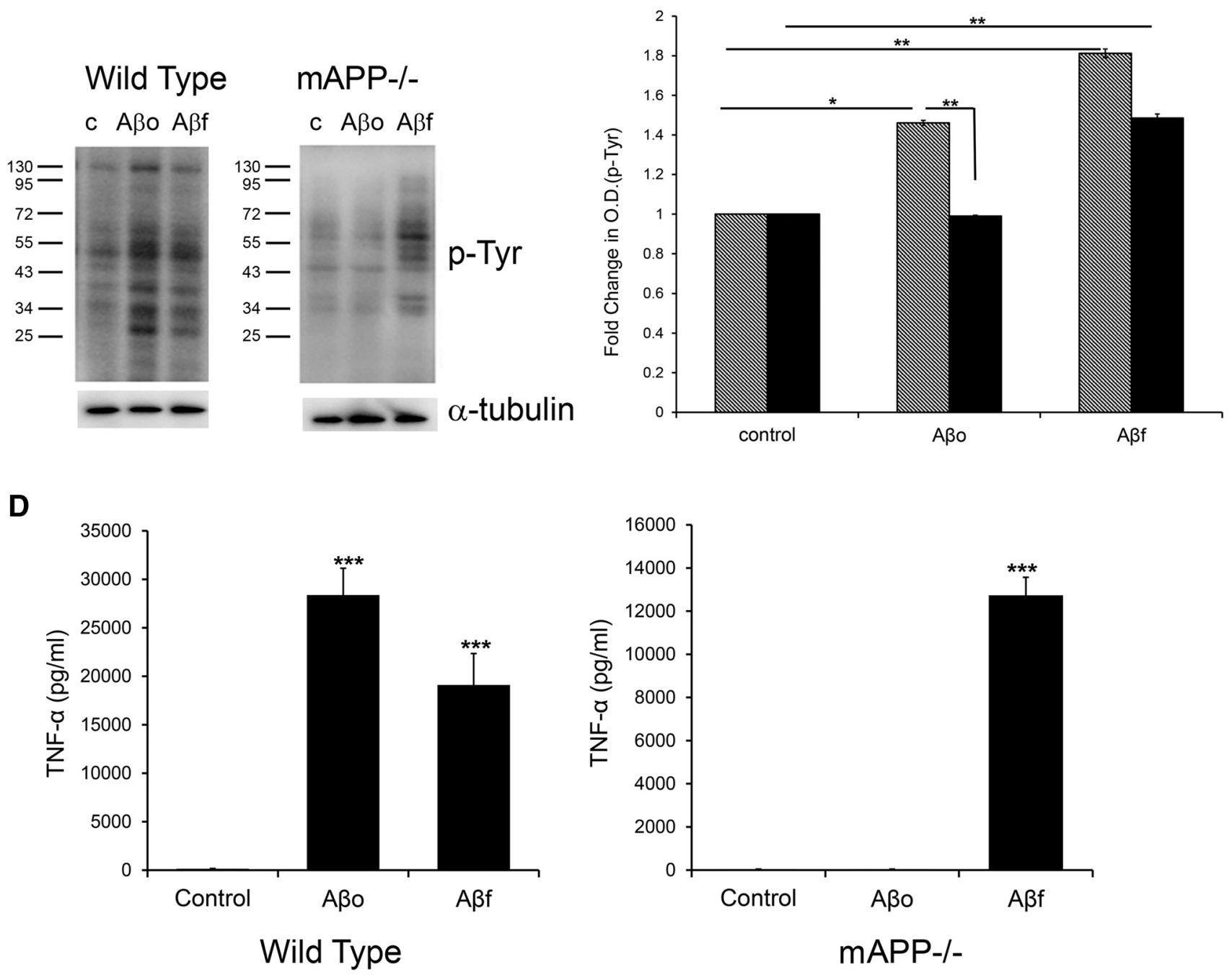

Figure 1. $A \beta$ oligomers stimulated increased protein phosphotyrosine levels and TNF- $\alpha$ secretion only in microglia and THP-1 cells expressing $A P P . A, A \beta$ oligomers $\left(A \beta_{0}\right)$ and $A \beta$ fibrils $\left(A \beta_{f}\right)$ were resolved on $15 \%$ denaturing polyacrylamide gels and Western blotted using anti-A $\beta$ (6E10) antibody. B, THP-1 cells were stimulated (5 min, $20 \mu \mathrm{M})$ with $A \beta_{0}$ and $A \beta_{\mathrm{f}}$ with or without a $24 \mathrm{~h}$ knockdown with APP siRNA. Cells were lysed and lysates resolved via 10\% SDS-PAGE and Western blotted using anti-phosphotyrosine (4G10) antibody along with anti-APP and anti-ERK-2 (loading control) antibodies. C, Microglia from (57BL/6 (Wild Type) and mAPP ${ }^{-1-}$ mice were stimulated with vehicle, $20 \mu \mathrm{m} \mathrm{A} \beta_{0}$, or A $\beta_{\mathrm{f}}$ for 5 min. Cells were lysed and lysates were separated by $10 \%$ SDS-PAGE and Western blotted with anti-phosphotyrosine (4G10) antibody and anti- $\alpha$-tubulin antibody (loading control). Densitometry analysis was performed and fold change in protein phosphotyrosine levels over control were plotted. D, Microglia from WT and mAPP ${ }^{-1-}$ mice were stimulated with $A \beta_{0}$ and $A \beta_{f}$ for $24 \mathrm{~h}$ and secreted TNF- $\alpha$ levels were determined using ELISA. TNF- $\alpha$ values were averaged ( \pm SEM). Blots and graphs are representative of three independent experiments $\left[{ }^{*} p<0.05,{ }^{* *} p<0.01,{ }^{* * *} p<0.001(C, D)\right]$. 
A
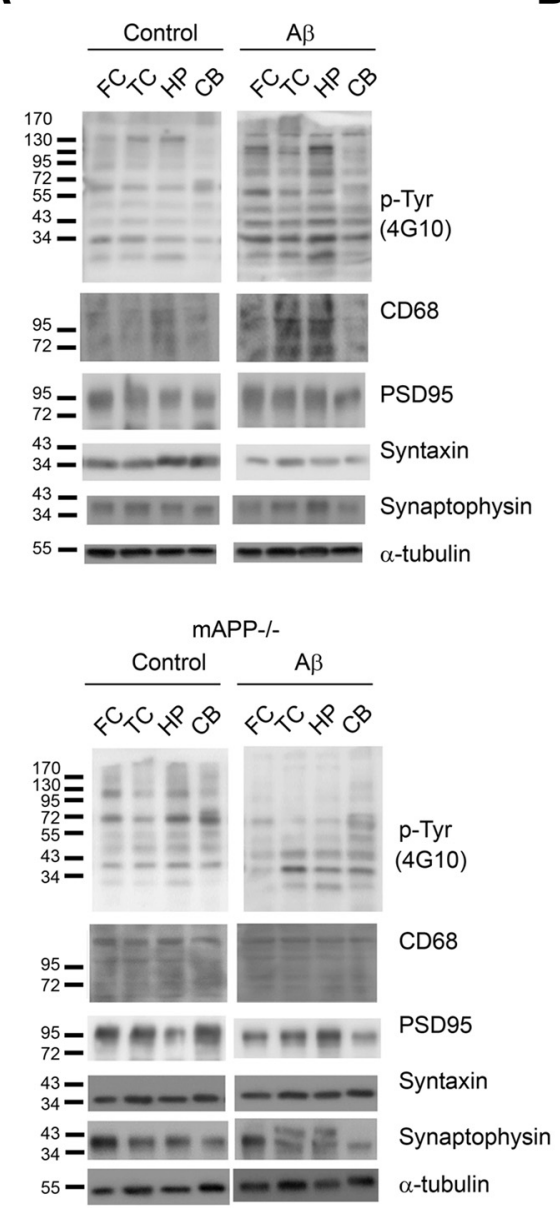

B
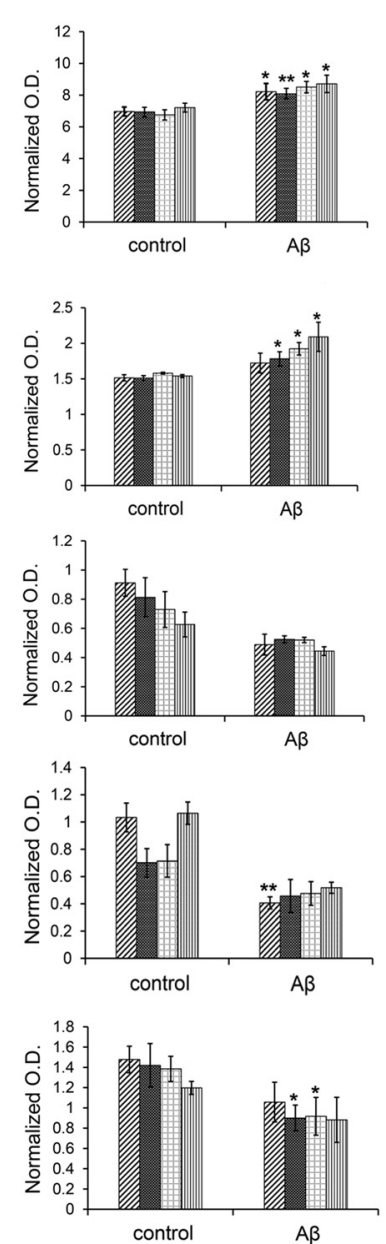

mAPP-/-

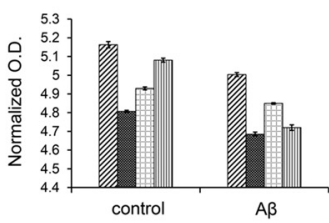

p-Tyr (4G10)
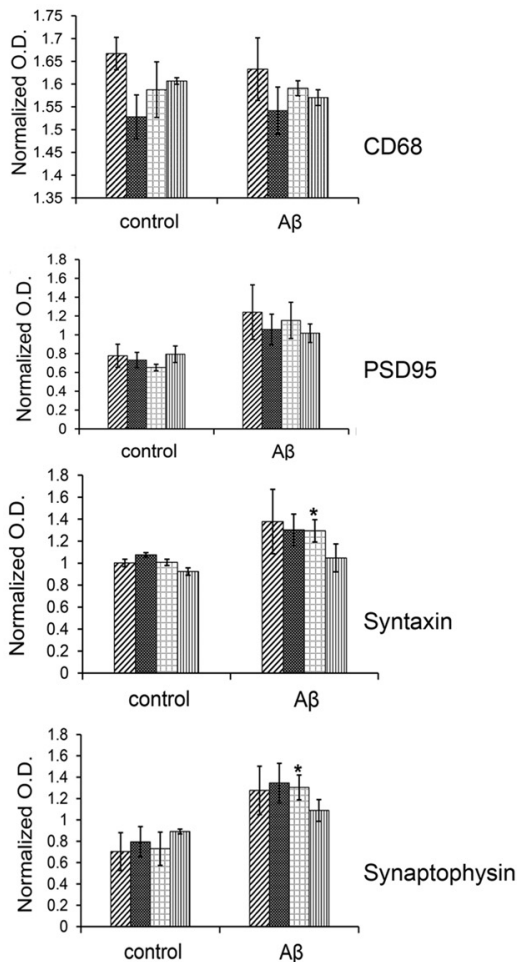

p-Tyr

(4G10)

Hippocampus

Cerebellum

SD95

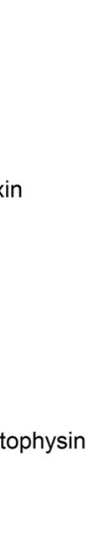

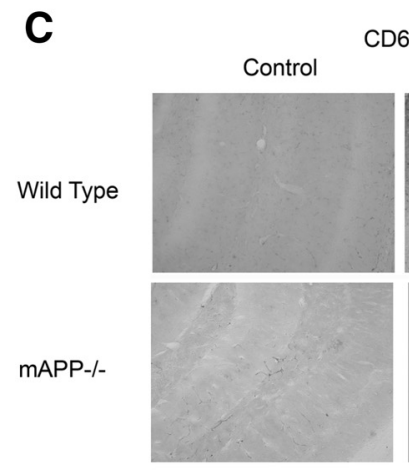

$A \beta$
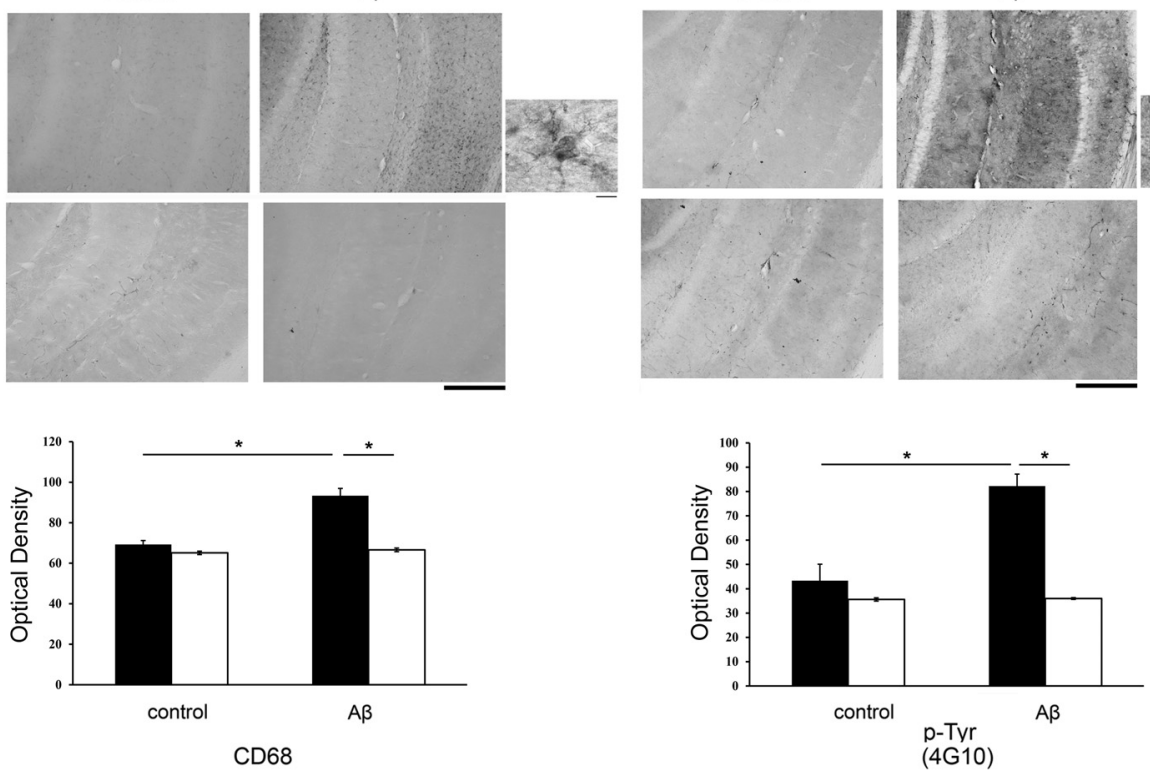

Wild Type

ImAPP-1-

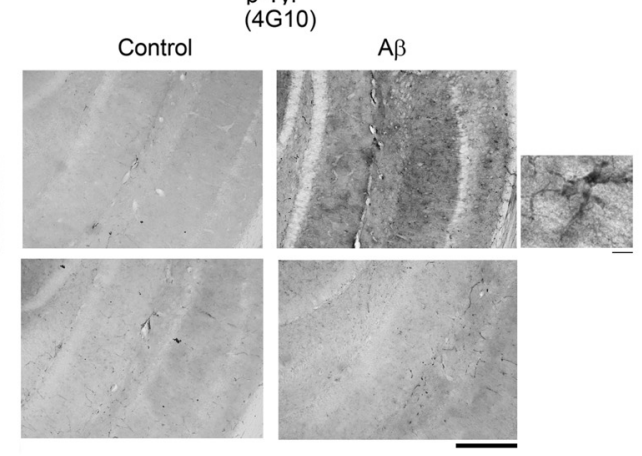

(4G10)

Figure 2. $A \beta$ oligomer infusion stimulated increased protein phosphotyrosine levels, increased microgliosis, and decreased neuronal marker proteins in WT but not mAPP $-/-$ mice. A $\beta$ oligomers were infused into the right lateral ventricle of 6-month-old, male C57BL/6 (Wild Type) and mAPP ${ }^{-1-}$ mice for $14 \mathrm{~d}$. $A$, Lysates prepared from brain left hemispheres [frontal cortex (FC), temporal cortex (TC), hippocampus (HP), and cerebellum (CB)] were resolved via 10\% SDS-PAGE and Western blotted with anti-phosphotyrosine (4G10), anti-CD68 (microglia marker), neuronal marker (anti-PSD95, anti-syntaxin, and anti-synaptophysin antibodies), and anti- $\alpha$-tubulin (loading control) antibodies. Representative blots of five animals per (Figure legend continues.) 
Intracerebroventricular $A \beta$ oligomers infusion increased total protein phosphotyrosine levels, increased microgliosis, and decreased neuronal marker proteins in WT but not $\mathrm{MAPP}^{-1-}$ mice

To validate the in vitro findings, we next determined whether oligomeric $\mathrm{A} \beta$ could stimulate similar tyrosine kinase-associated microgliosis in vivo using $\mathrm{C} 57 \mathrm{BL} / 6$ (WT) and $\mathrm{mAPP}^{-1-}$ mice. The mice were intracerebroventricularly infused with vehicle or oligomeric $\mathrm{A} \beta$ for $14 \mathrm{~d}$ as in our prior work (Dhawan et al., 2012). As expected, oligomeric A $\beta$ infusion into WT mice stimulated increased total protein phosphotyrosine (4G10) levels in all four regions of the brain analyzed: frontal cortex, temporal cortex, hippocampus, and cerebellum (Fig. 2A,B). Microgliosis, examined by CD68 protein levels, was also increased in the temporal cortex, hippocampus, and cerebellum of oligomeric $\mathrm{A} \beta$-infused mice (Fig. $2 A, B$ ). These changes in protein levels correlated with increased phosphotyrosine and CD68 immunoreactivity as assessed in the hippocampus of the WT infused mice (Fig. 2C). In agreement with the in vitro findings, oligomeric $\mathrm{A} \beta$ infusion into $\mathrm{mAPP}^{-1-}$ mice stimulated no increase in phosphotyrosine or CD68 protein levels or immunoreactivity (Fig. $2 A-C$ ). A $\beta$ oligomer infusion into WT mice also led to a reduction in neuronal protein markers PSD95, syntaxin, and synaptophysin in several of the brain regions examined correlating with the microgliosis (Fig. 2B).

$A P P / P S 1 \times m A P P^{-1-}$ mice had limited transgene expression in microglia and altered A $\beta$ plaque pathology compared with APP/ PS1 mice

The in vitro and infusion findings supported the idea that endogenous APP, particularly on microglia, was needed for microgliosis in response to oligomeric $\mathrm{A} \beta$ stimulation. To further validate this idea through a genetic strategy, we next crossed an APP/PS1 mouse line mice expressing the human Swedish APP and $\Delta$ E9 presenilin 1 (PS1) mutant proteins with $\mathrm{mAPP}^{-/-}$mice to eliminate endogenous mouse APP. To validate the expression of human or mouse APP, brains of 10-month-old male WT (C57BL/ 6), $\mathrm{APP} / \mathrm{PS} 1, \mathrm{mAPP}^{-1-}$, and the crossed (APP/PS1 $\times \mathrm{mAPP}^{-1-}$ ) mice were examined. Western blotting using anti-APP (Y188) antibody to measure total APP levels (murine and human) demonstrated a significant increase in the APP/PS1 and APP/ PS $1 \times \mathrm{mAPP}^{-/-}$mouse temporal cortices as expected (Fig. $3 A$ ). Also as expected, rodent APP was observed only in WT and APP/ PS1 temporal cortices and was absent in $\mathrm{mAPP}^{-1-}$ and APP/ $\mathrm{PS} 1 \times \mathrm{mAPP}^{-1-}$ mice, demonstrating that the crossed mice carried only the transgene APP (Fig. 3A). Based upon the overexpression of APP observed, we compared $\mathrm{A} \beta$ plaque pathology in the four lines. The APP/PS1 mice demonstrated a characteristic plaque load assessed by thioflavin $\mathrm{S}$ staining and anti-A $\beta$ (4G8, BAM10) staining (Fig. 3 B, C). However, despite a similar APP transgene expression, the APP/PS1 $\times \mathrm{mAPP}^{-1-}$ mice had decreased thioflavin S and 4G8 staining and nearly completely attenuated BAM10 A $\beta$ immunoreactivity (Fig. $3 \mathrm{~B}, \mathrm{C}$ ). Although the prion promoter is likely to drive expression in cell types beyond neurons in the APP/PS $1 \times \mathrm{mAPP}^{-1-}$ mice, Western blot

\section{$\leftarrow$}

(Figure legend continued.) group are shown. $\boldsymbol{B}, 0$ ptical density (0.D.) was measured, averaged, and plotted ( \pm SEM; $\left.{ }^{*} p<0.05,{ }^{* *} p<0.01\right)$. C, Right hemispheres of brains were fixed in $4 \%$ paraformaldehyde, sectioned, and immunostained using anti-phosphotyrosine (4G10) and anti-CD68 antibodies. Representative images (arrows) from five animals per group at $10 \times$ magnification are shown from the $C A 1$ region of the hippocampus with inserts at $63 \times$ magnification. Quantitation of immunostaining was performed and $0 . D$. values were averaged and $\operatorname{plotted}\left( \pm\right.$ SEM; $\left.{ }^{*} p<0.05\right)$. validation ensured that the transgene was not readily detectable in microglia cultures, suggesting that the brains of these animals, although highly expressive for mutant APP in neurons, were deficient in microglial APP (Fig. 3D). This was further examined by comparing endogenous levels of APP in cultures of murine neurons, astrocytes, and microglia compared with human microglia. Murine microglial APP protein levels, while present, were reduced compared with neurons (Fig. $3 E$ ). Human microglia also expressed APP, demonstrating species conservation (Fig. 3E). Levels of murine $\mathrm{A} \beta$ secreted from microglial cultures were quantified with no detectable A $\beta 1-42$ (data not shown) and levels of $A \beta 1-40$ not above the ELISA kit background, since there was no difference in the $\mathrm{A} \beta 1-40$ concentration values between microglia cultures prepared from WT and $\mathrm{mAPP}^{-1-}$ mice (Fig. $3 F$ ). These data verified that microglia normally express mAPP and hAPP in mice and humans, respectively, although the mutant human transgene was not detectably expressed in mouse microglia. Moreover, APP may not be processed to A $\beta$ in these cells.

APP/PS1 $\times m A P P^{-1-}$ mice had attenuated microgliosis compared with APP/PS1 mice

To examine whether the absence of APP had the predicted effects on microgliosis in vivo, we next compared levels of markers for microglial activation in the 10-month-old male WT, APP/PS1, $\mathrm{mAPP}^{-1-}$, and APP/PS1 $\times \mathrm{mAPP}^{-/-}$mice. Although CD $11 \mathrm{~b}$ and Iba- 1 are pan-microglia markers, they have been useful in identifying $\mathrm{A} \beta$ plaque-associated microglia in APP/PS1 mice (Radde et al., 2006; Combs, 2009). In confirmation of this prior work, we observed increased CD11b and CD68 immunoreactivity (Fig. 4A), as well as an increased number of Iba-1-positive cells (Fig. $4 B$ ) in these mice compared with WT (C57BL/6) and $\mathrm{mAPP}^{-1-}$ mice. However, despite the continued presence of $\mathrm{A} \beta$ plaques in the $\mathrm{APP} / \mathrm{PS} 1 \times \mathrm{mAPP}^{-/-}$mice, they had significantly lower immunoreactivity and total protein levels of several microglial activation markers, including phosphotyrosine, CD68, and CD11b levels in the temporal cortex (Fig. 4A,C) and hippocampus (data not shown), indicating that endogenous APP is required for $\mathrm{A} \beta$ plaque-associated microgliosis. The total number of Iba-1-positive microglia in the temporal cortex of each of the four genotypes of mice were estimated using unbiased stereological analyses and, as expected, the number of Iba-1-positive microglia in the APP/PS $\times \mathrm{mAPP}^{-1-}$ mice were also significantly lower than in the APP/PS1 mice (Fig. 4B).

\section{$m A P P^{-1-}$ and $A P P / P S 1 \times m A P P^{-/-}$microglia had reduced} migratory ability

The APP/PS1 $\times \mathrm{mAPP}^{-/-}$mice had attenuated microgliosis despite the presence of significant $A \beta$ plaques. Although this could be due to loss of $\mathrm{A} \beta$-stimulated microglial activation, we also tested the hypothesis that limited microgliosis was related to attenuated microglial migratory ability. To determine whether microglia lacking APP had an altered overall phenotype, primary microglia from WT, APP/ $\mathrm{PS} 1, \mathrm{mAPP}^{-/-}$, and APP/PS $1 \times \mathrm{mAPP}^{-/-}$mice were cultured and phagocytosis, migration, and proliferation assays were performed. There were no differences in phagocytosis ability between the four strains of microglia (Fig. 5A). However, both the $\mathrm{mAPP}^{-1-}$ and $\mathrm{APP} / \mathrm{PS} 1 \times \mathrm{mAPP}^{-/-}$microglia had significantly attenuated chemokine-stimulated migratory ability compared with WT and APP/PS1 mice (Fig. 5B). Surprisingly, both APP/PS1 and APP/ $\mathrm{PS} 1 \times \mathrm{mAPP}^{-1-}$ microglia had decreased proliferation compared with WT and $\mathrm{mAPP}^{-1-}$ mice (Fig. $5 C$ ). These data suggested that the lack of plaque-associated microgliosis in the APP/ $\mathrm{PS} 1 \times \mathrm{mAPP}^{-/-}$mice could be a combination of attenuated re- 
A

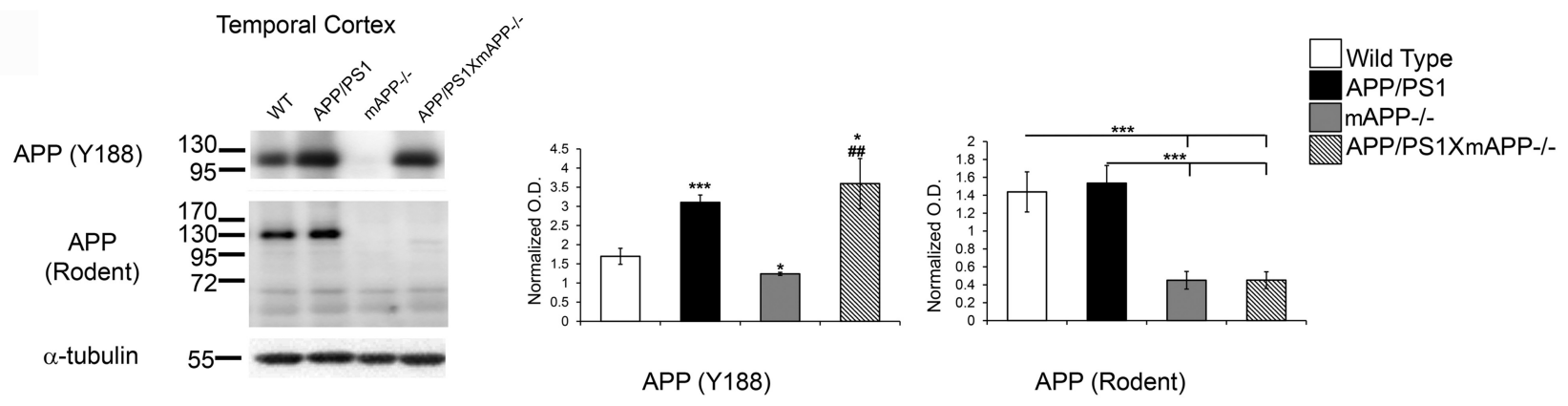

B

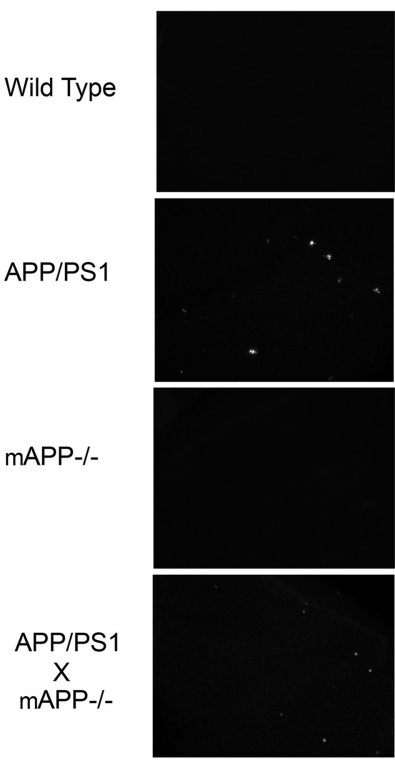

Thioflavin

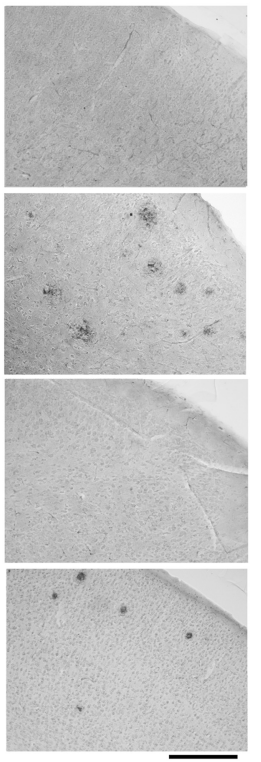

$A \beta(4 G 8)$
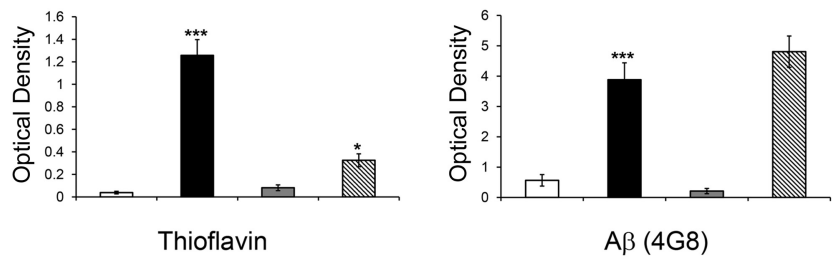

A $\beta$ (Rodent)

C

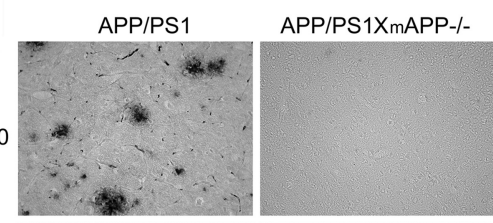

D

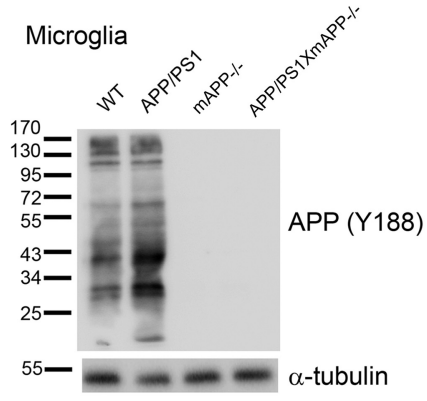

E

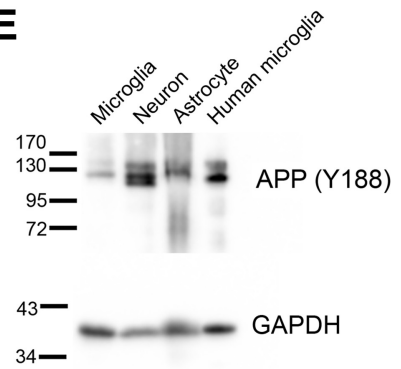

F

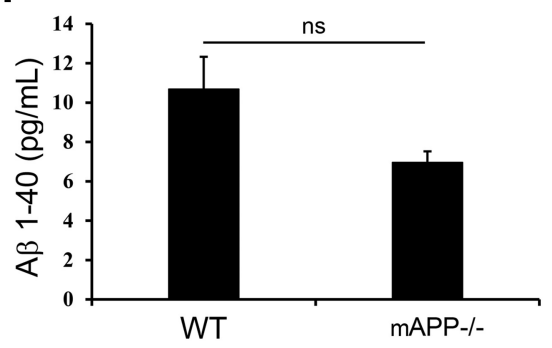

Microglia

Figure 3. APP/PS1 $\times \mathrm{mAPP}^{-1-}$ mice had limited transgene expression in microglia and altered A $\beta$ plaque pathology compared with APP/PS1 mice. A, Temporal cortices from left brain hemispheres from 10-month-old C57BL/6 [Wild Type (WT)] mice, APP/PS1 mice, mAPP ${ }^{-1-}$, and APP/PS1 $\times \mathrm{mAPP}^{-1-}$ mice were lysed and resolved via SDS-PAGE and Western blotted using anti-APP Y188 (human and rodent specific), anti-A $\beta$ (rodent specific), and $\alpha$-tubulin antibodies (loading control). Optical densities were measured, averaged, and plotted ( \pm SEM). B, Brain sections from 10-month-old C57BL/6 (WT) mice, APP/PS1 mice, mAPP ${ }^{-1-}$, and APP/PS1 $\times \mathrm{mAPP}^{-1-}$ mice were paraformaldehyde fixed, sectioned, and immunostained using anti-A $\beta$ (4G8) antibody or stained with thioflavin $S$. Representative images from $\geq 10$ animals per group are shown at $10 \times$ magnification. Quantitation of immunostaining was performed and optical density (0.D.) values were averaged and plotted [ \pm SEM; $\left.{ }^{*} p<0.05,{ }^{* *} p<0.01,{ }^{* * *} p<0.001(\boldsymbol{A}, \boldsymbol{B})\right]$. C, Brain sections from 10-month-old APP/PS1 mice

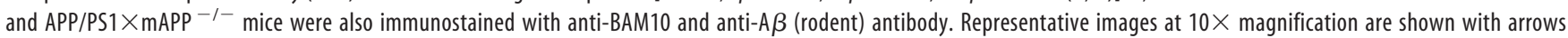
representing positive immunostaining. $\boldsymbol{D}$, Microglia from WT, APP/PS1, $\mathrm{mAPP}^{-1-}$, and APP/PS1 $\times \mathrm{mAPP}^{-1-}$ mice [postnatal day (P) $0-\mathrm{P3}$ ] were cultured. Cells were lysed, resolved via SDS-PAGE, and Western blotted using anti-APP (Y188) and $\alpha$-tubulin antibodies. $E$, Primary murine microglia, neuron, astrocyte, and human microglia cell lysates were resolved via SDS-PAGE and Western blotted using anti-APP (Y188) and GAPDH antibodies. $F$, Primary microglia cultures from WT (C57BL/6) and mAPP ${ }^{-1-}$ mice were prepared and culture media was used to perform A $\beta 1-40$ ELISA. 
A
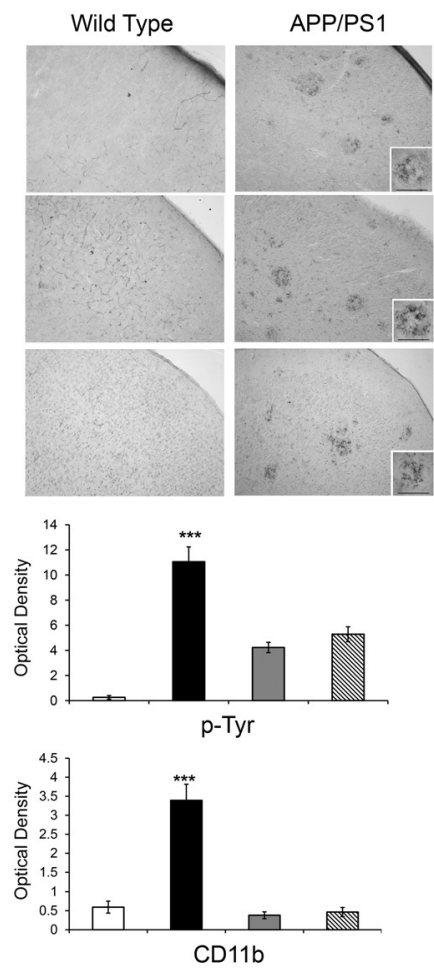

mAPP-1-
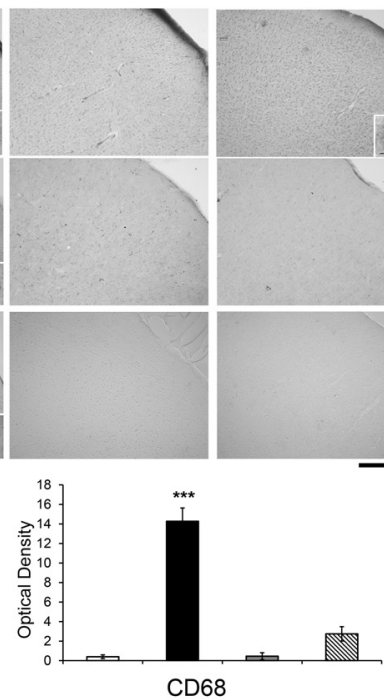

CD68

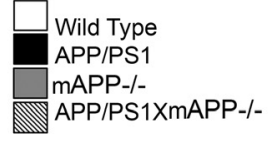

B

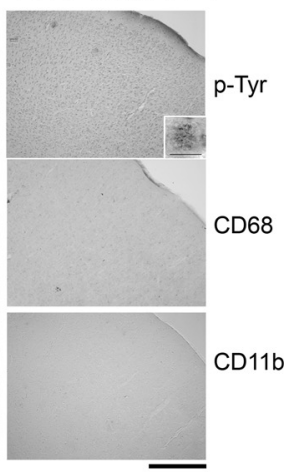

CD68
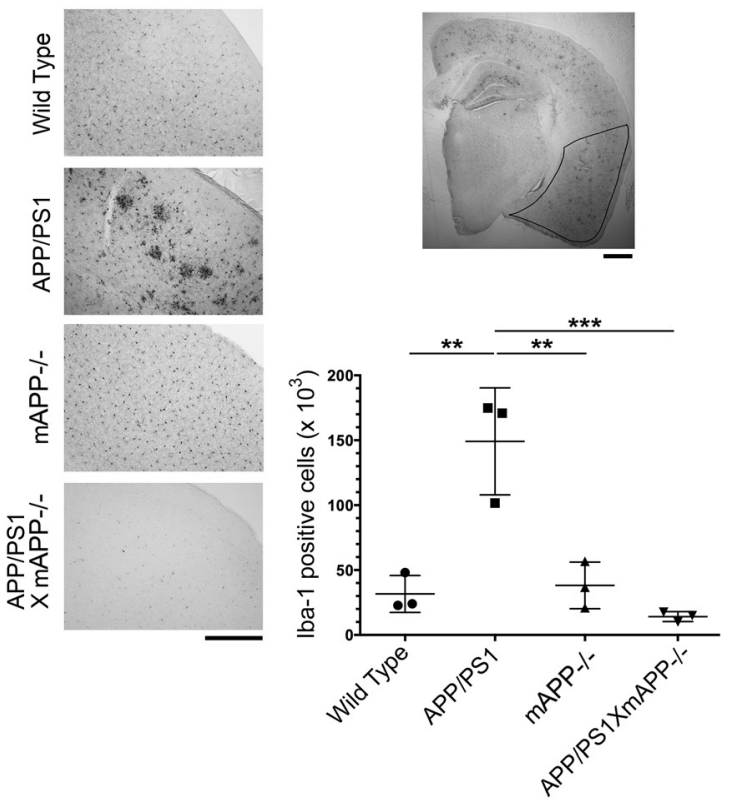

C
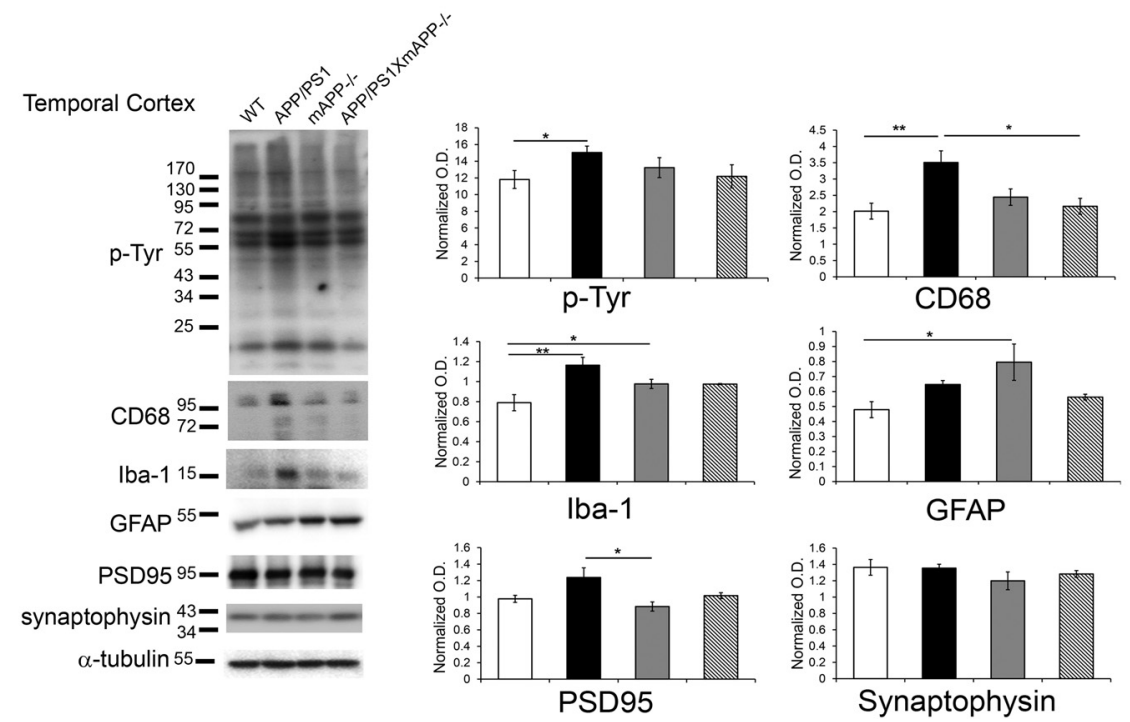

GFAP

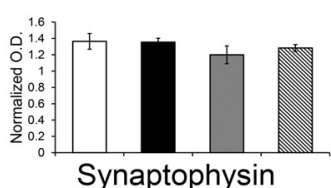

Figure 4. APP/PS1 $\times \mathrm{mAPP}^{-1-}$ mice had attenuated microgliosis and phosphotyrosine immunoreactivity. $A$, Brains from 10-month-old C57BL/6 [Wild Type (WT)], APP/PS1, mAPP ${ }^{-/-}$, and APP/PS1 $\times \mathrm{mAPP}^{-1-}$ mice were collected and right hemispheres fixed in paraformaldehyde. Hemispheres were sectioned and immunostained using anti-phosphotyrosine (4G10), anti-CD68, and anti-CD11b antibodies. Representative images from $\geq 10$ animals per group are shown at $10 \times$ magnification (insets show $63 \times$ magnification). Quantitation of immunostaining was performed and optical density values were averaged and plotted ( \pm SEM). B, Brains from 10-month-old C57BL/6 (Wild Type), APP/PS1, mAPP ${ }^{-1-}$, and APP/PS1 $\times \mathrm{mAPP}^{-1-}$ mice were immunostained using anti-lba-1 antibody and Iba-1-positive cells were counted using Stereology Investigator software, averaged, and plotted ( \pm SEM; $\left.{ }^{*} p<0.05\right)$. C, Left brain hemispheres from 10-month-old C57BL/6 (WT), APP/PS1, mAPP ${ }^{-1-}$, and APP/PS1 $\times \mathrm{mAPP}^{-1-}$ mice were further dissected out into hippocampus and temporal cortex and lysed. Lysates from temporal cortex were then resolved via SDS-PAGE and Western blotted using anti-phosphotyrosine (4G10), anti-CD68, anti-PSD95, anti-GFAP, anti-Iba-1, anti-synaptophysin, and anti- $\alpha$-tubulin antibodies. Representative blots from $\geq 7$ animals per group are shown. Optical densities were measured, averaged, and plotted ( \pm SEM; ${ }^{*} p<0.05,{ }^{* *} p<0.01$, ${ }^{* *} p<0.001$ ).

sponse to $\mathrm{A} \beta$ stimulation as well as less chemoattraction toward plaques.

Oligomeric A $\beta$ interacted with APP in a concentration-dependent manner

To better validate the possibility of a direct $\mathrm{A} \beta$-APP interaction as a possible source of microglial activation, the ability of $A \beta$ oligomers and fibrils to interact with APP was determined using a modified ELISA protocol wherein A $\beta$ bound to APP was detected using an $\mathrm{A} \beta$-selective antibody with no cross-reactivity to APP.
$\mathrm{A} \beta$ oligomer interacted with APP in a dose-response manner whereas fibrillar A $\beta$ failed to bind to APP in levels appreciably above the assay background (Fig. $6 A$ ). These data supported the notion that a specific interaction between $\mathrm{A} \beta$ oligomers and APP on the microglial surface can drive microgliosis independent from that stimulated by fibrillar $\mathrm{A} \beta$. To assess any affinity differences of the anti-A $\beta$ antibody MOAB- 2 for oligomeric and fibrillar $\mathrm{A} \beta, 2 \mu \mathrm{g}$ of prepared peptides (oligomer and fibril) were dot blotted onto a PVDF membrane and detected using the antibody. 
A

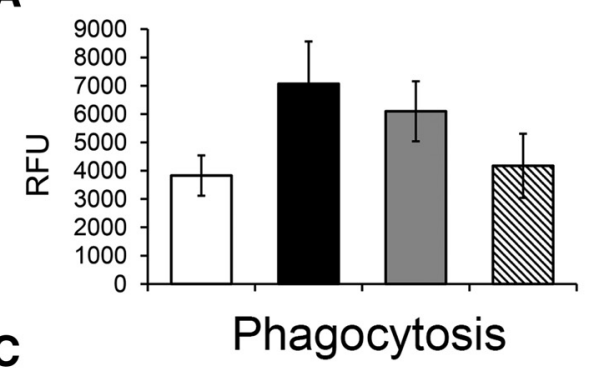

C

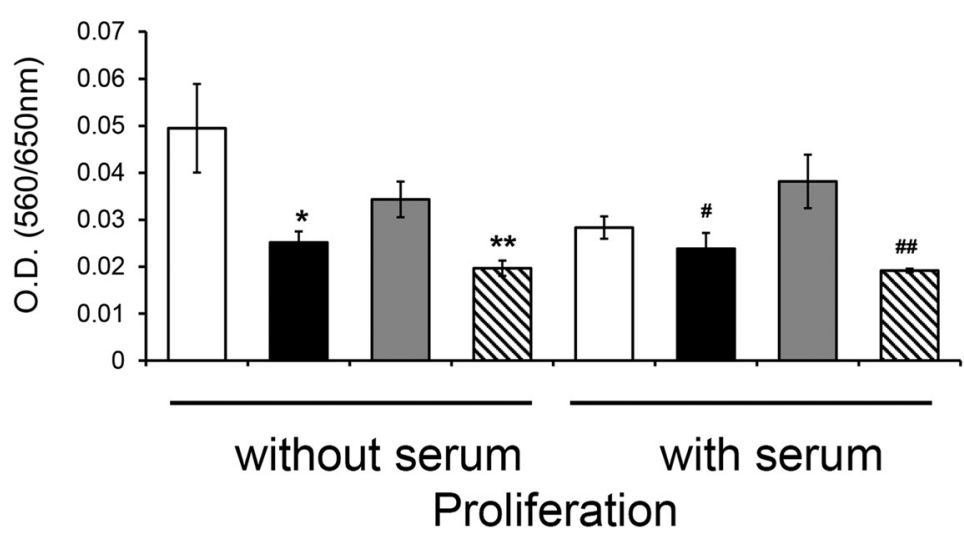

B

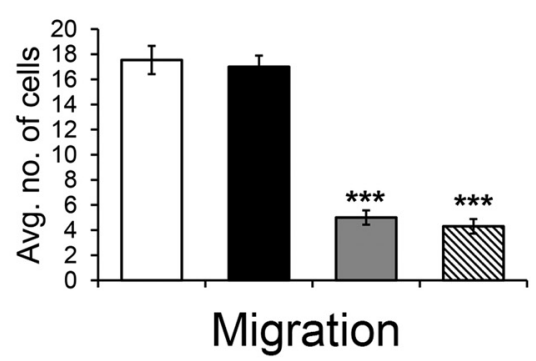

Figure 5. Microglial cultures from $\mathrm{mAPP}^{-/-}$mice and APP/PS1 $\times \mathrm{mAPP}^{-/-}$mice had reduced chemokine-induced migratory ability compared with WT and APP/PS1 mice. Microglia from WT, APP/PS1, mAPP $-1-$, and APP/PS1 $\times \mathrm{mAPP}^{-1-}$ mice [postnatal day (P) $0-P 3$ ] were cultured to quantify microglial behavior. $\boldsymbol{A}$, To assess phagocytic ability, microglia were incubated with fluorescein-conjugated Escherichia coli (K-12 strain) BioParticles for $6 \mathrm{~h}$, then extracellular signal quenched by rinsing with $0.25 \mathrm{mg} / \mathrm{ml}$ trypan blue. Intracellular fluorescence was read (excitation, $480 \mathrm{~nm}$; emission, $520 \mathrm{~nm}$ ) via fluorescent plate reader. $\boldsymbol{B}$, To compare migration ability, microglia were plated into the upper chamber of transwell inserts and allowed to migrate into the lower chamber containing $100 \mathrm{ng} / \mathrm{ml}$ murine MCP-1 for $6 \mathrm{~h}$. The transwells were removed and cells that had migrated through to the bottom of the well were counted and averaged ( \pm SD; ${ }^{* * *} p<0.001$ ). C, To compare proliferative ability, microglia from each of the genotypes were plated onto a 96 -well plate for $24 \mathrm{~h}$ in the absence or presence of mitogen-enriched media containing $10 \%$ FBS/5\% horse serum. The media were removed and $100 \mu \mathrm{g} / \mathrm{ml} \mathrm{MTT}$ was added to the cultures for $4 \mathrm{~h}$ at $37^{\circ} \mathrm{C}$. Media were aspirated and the reduced formazan precipitate was dissolved in isopropanol and absorbances were read at 560/650 nm via plate reader (without serum: ${ }^{*} p<0.05$, ${ }^{* *} p<0.01$; with serum: \#p $<0.05$, \#\#p $<0.01$ ).

As shown in the figure, the anti-A $\beta$ antibody MOAB-2 was able to recognize both oligomeric and fibrillar $\mathrm{A} \beta$ (Fig. $6 A$, inset). To further authenticate a direct $\mathrm{A} \beta \mathrm{O}-\mathrm{APP}$ binding, oligomers prepared from fluorescein-labeled $\mathrm{A} \beta$ (FITC-A $\beta \mathrm{O}$ ) were used. FITC-A $\beta$ oligomers were first confirmed to have a similar migration pattern by SDS-PAGE as the unlabeled $\mathrm{A} \beta$ oligomers (Fig. $6 B)$. To perform the binding studies, a human APP construct was expressed in GripTite 293 MSR cells. Cell-surface localization of APP was confirmed by immunostaining transfected cells with anti-N-terminal APP antibody in the absence of detergent (Fig. $6 C)$. There was a concentration-dependent increase in RFUs quantified from APP-transfected cells incubated with FITC-A $\beta \mathrm{o}$ compared with mock-transfected cells (Fig. 6D), suggesting specific binding between FITC-A $\beta$ o and the transfected APP binding site expressed on GripTite cells. To further confirm the specific binding and estimate affinity of FITC-A $\beta$ o for APP, a mixture of anti-N-terminal APP antibodies was used to define nonspecific binding. Increasing concentrations of FITC-A $\beta \mathrm{O}$ specifically labeled a saturable, homogenous, high-affinity binding site on APP-transfected cells (Fig. 6E). The equilibrium dissociation constant $\left(K_{\mathrm{d}}\right)$ of FITC-A $\beta$ o for this specific APP binding site was calculated to be $5.3 \pm 1.8 \mathrm{~nm}$. To substantiate this APP binding site as the physiological receptor, unlabeled A $\beta$ oligomer was used to compete for specific binding sites identified by FITC-A $\beta$ o. Increasing concentrations of unlabeled $A \beta$ oligomer decreased the RFUs of bound FITC-A $\beta$ o with an $\mathrm{IC}_{50}$ of $14.0 \pm 2.1 \mathrm{~nm}$ (Fig. $6 F$ ). Using the method of Cheng and Prusoff (1973), the equilibrium dissociation constant $\left(K_{\mathrm{i}}\right)$ of unlabeled
$\mathrm{A} \beta$ oligomer for the specific APP binding site was calculated to be $1.3 \pm 0.2 \mathrm{nM}$.

APP/PS $1 \times m A P P^{-1-}$ mice had attenuated TNF- $\alpha$ and IL- 6 levels Although microgliosis was attenuated in the APP/PS1 $\times$ $\mathrm{mAPP}^{-1-}$ mice, microglia are not the only cell type involved in mediated brain inflammatory changes. To determine whether the altered microgliosis in $\mathrm{APP} / \mathrm{PS} 1 \times \mathrm{mAPP}^{-1-}$ mice correlated with attenuated inflammatory changes in the brain, parietal cortices mRNA from WT, APP/PS1, $\mathrm{mAPP}^{-1-}$, and APP/ $\mathrm{PS} 1 \times \mathrm{mAPP}^{-1-}$ mice were analyzed for cytokines using realtime PCR. Levels of TNF- $\alpha$, IL-6, and IL-10 mRNA were determined as representative cytokines. Correlating with the reduced phosphotyrosine levels and microgliosis in the brain, APP/ PS $1 \times \mathrm{mAPP}^{-1-}$ mice had reduced TNF- $\alpha$ and IL- 6 mRNA levels in the parietal cortex with no significant differences in antiinflammatory IL-10 levels compared with APP/PS1 mice (Fig. $7 A$ ). Protein levels of TNF- $\alpha$ were also reduced in APP/ $\mathrm{PS} 1 \times \mathrm{mAPP}^{-1-}$ mice by a fraction similar to that for reduced mRNA levels (Fig. 7B). These data demonstrated a reduced proinflammatory state in the brains of APP/PS1 $\times \mathrm{mAPP}^{-/-}$mice.

$A P P / P S 1 \times m A P P^{-1-}$ mice had improved memory performance, increased exploratory behavior, and reduced anxiety compared with APP/PS1 mice

To determine whether the loss of APP and the reduced gliosis and cytokine levels in the APP/PS $1 \times \mathrm{mAPP}^{-1-}$ mice resulted in improved behavioral outcomes, these mice were examined in the open-field, light/dark box, and T-maze paradigms. Interestingly, 

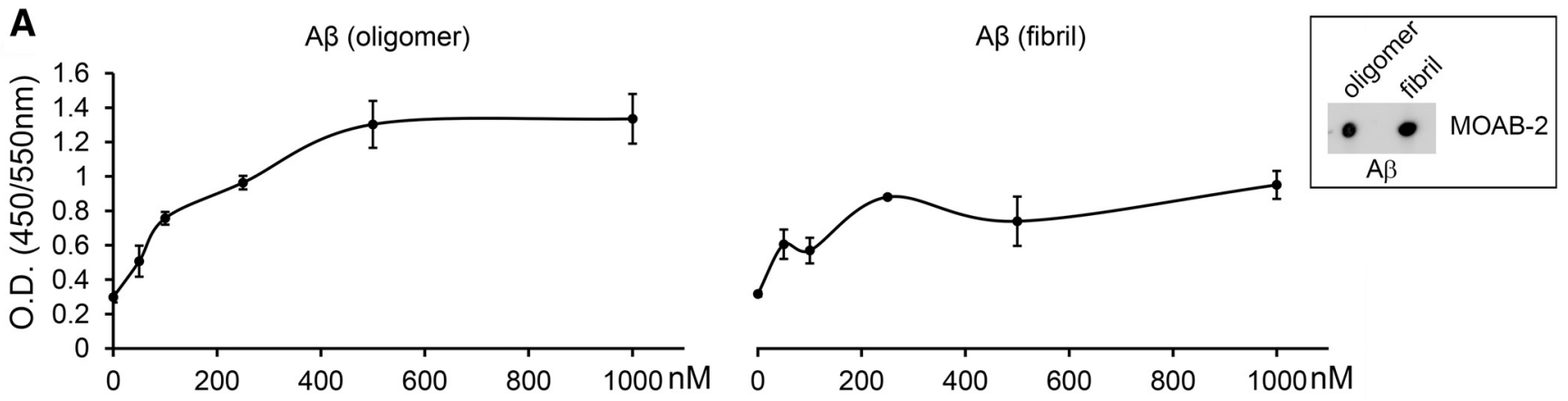

B

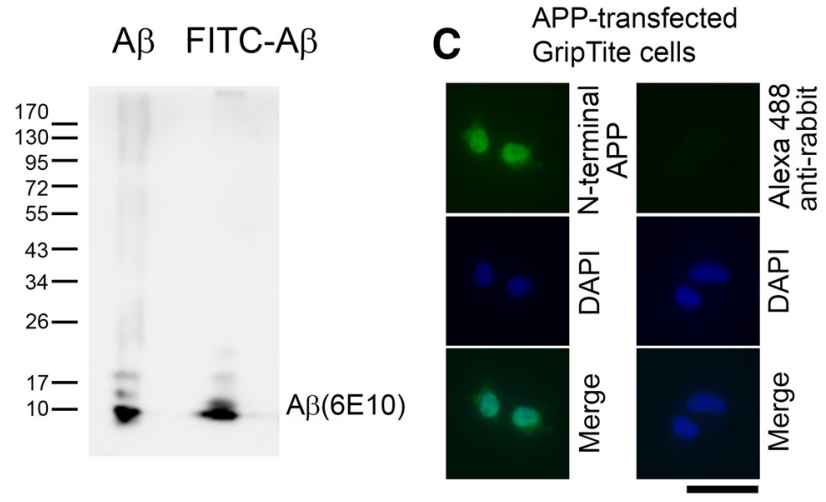

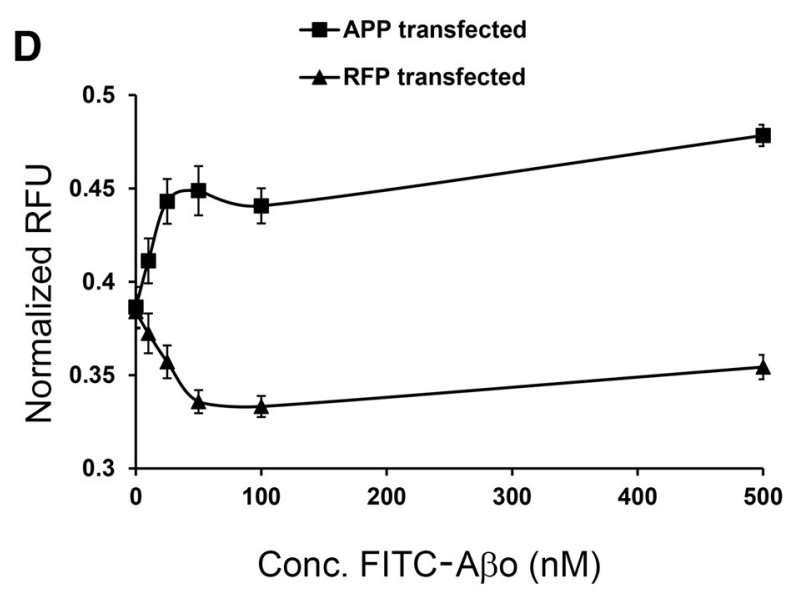

$\mathbf{F}$

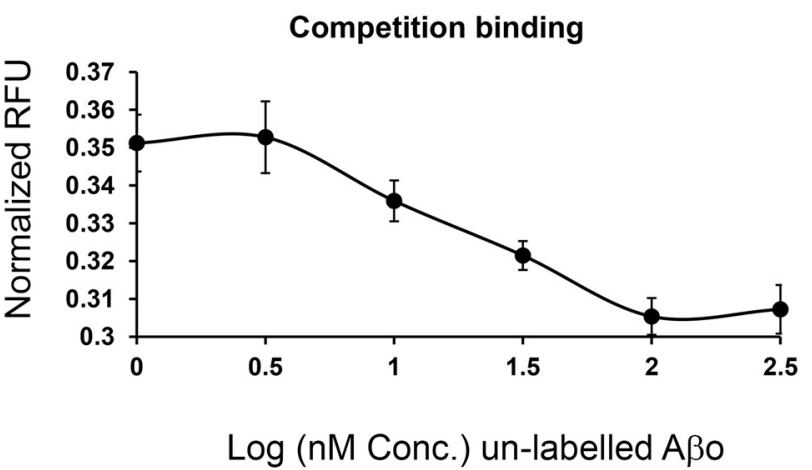

Figure 6. Oligomeric $A \beta$ interacted with APP in a concentration-dependent manner. $A$, Recombinant human APP-coated plates were incubated with increasing amounts of oligomeric and fibrillar $A \beta$ and detected using anti-A $\beta$ (MOAB-2 antibody). Optical density (0.D.) values were measured from three independent experiments was averaged and plotted ( \pm SEM). Prepared $A \beta$ (oligomer) and $A \beta$ (fibril) were each dot blotted ( $2 \mu \mathrm{g}$ ) onto PVDF membranes and detected using anti-A $\beta$ antibody MOAB-2 (inset). B, Oligomers prepared from unlabeled $A \beta$ and FITC-labeled A $\beta$ were prepared and resolved via SDS-PAGE and Western blotted using 6E10 antibody. C, GripTite 293 MSR cells are transfected with APP695 plasmid, paraformaldehyde fixed, and immunolabeled using $\mathrm{N}$-terminal APP antibody in the absence of detergent to identify cell-surface APP. D, APP-transfected or mock-transfected (RFP) GripTite cells were incubated with FITC-A $\beta$ o for $15 \mathrm{~min}$ and fluorescence intensity read at $490 / 525 \mathrm{~nm}$. $\boldsymbol{E}$, To identify FITC-A $\beta 0$-specific binding, APP-transfected cells were unblocked or blocked using a mix of N-terminal APP antibodies for 30 min followed by a 15 min incubation with increasing concentrations of FITC-A $\beta$ oligomer. Cells were washed with DMEM and the fluorescence read at $490 / 525 \mathrm{~nm}$. $\boldsymbol{F}$, Competition binding assay was performed by independently incubating APP-transfected GripTite cells with increasing concentrations of unlabeled A $\beta$ oligomer for $30 \mathrm{~min}$ followed by incubation with $50 \mathrm{~nm} \mathrm{FITC} A \beta$ oligomer for $15 \mathrm{~min}$. Following measurements of FITC-A $\beta 0$ intensities, all the cells were paraformaldehyde fixed, counterstained with DAPI, and the fluorescence intensity read at $360 / 450 \mathrm{~nm}$. Florescence intensity of bound FITC-A $\beta 0$ was normalized against DAPI, averaged, and plotted ( \pm SEM).

the compromise in open-field exploratory behavior demonstrated by the APP/PS1 mice was not present in the APP/ PS $1 \times \mathrm{mAPP}^{-1-}$ mice (Fig. $8 B$ ). However, both APP/PS1 and $\mathrm{APP} / \mathrm{PS} 1 \times \mathrm{mAPP}^{-1-}$ mice had reduced time spent and exploration in the center of the open field compared with WT mice, suggesting that both mice shared an anxiety phenotype (Fig. $8 B$ ).
To better assess this possibility, performance in the light/dark box paradigm was examined for each line. The APP/PS1 mice had a longer latency to the first entry into the dark side of the box, correlating with less mobility and more overall time spent in the light portion, compared with the APP/PS1 $\times \mathrm{mAPP}^{-/-}$mice (Fig. $8 C$ ). This suggested that the APP/PS1 $\times \mathrm{mAPP}^{-1-}$ mice had 

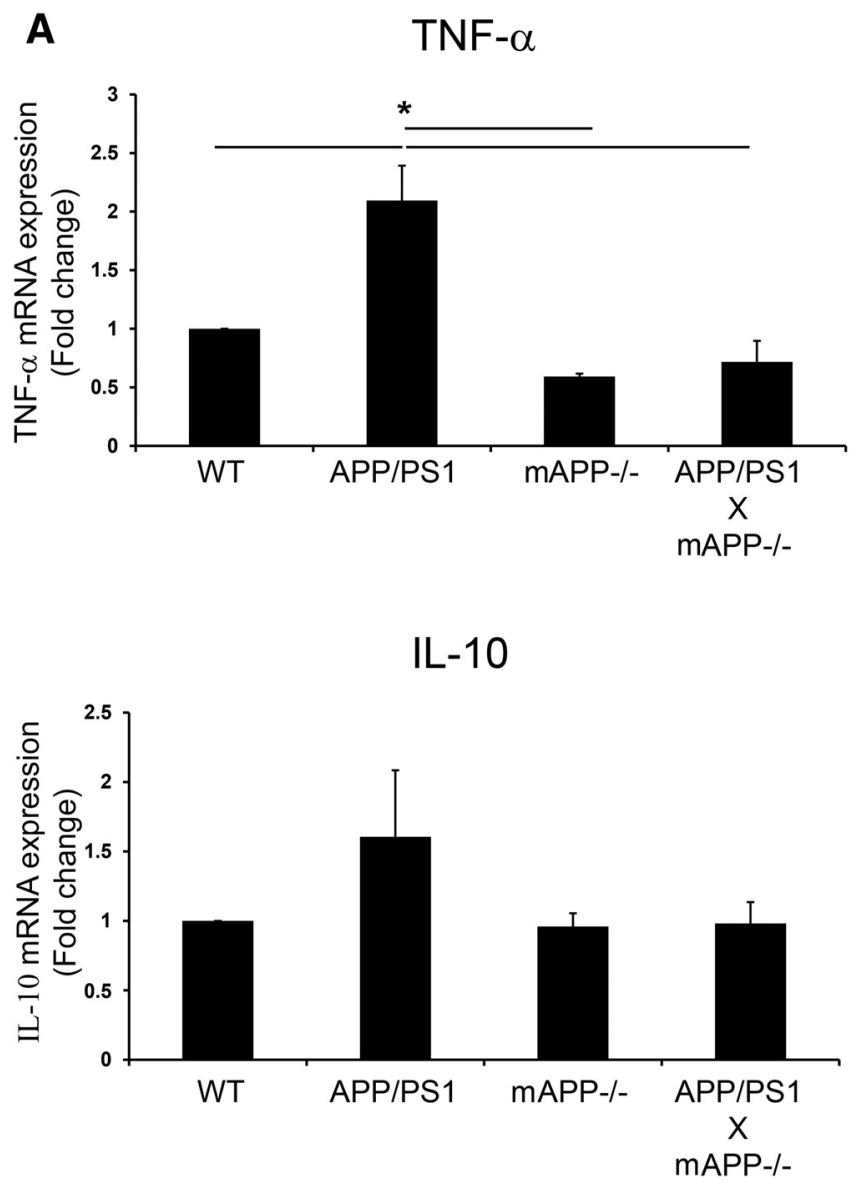

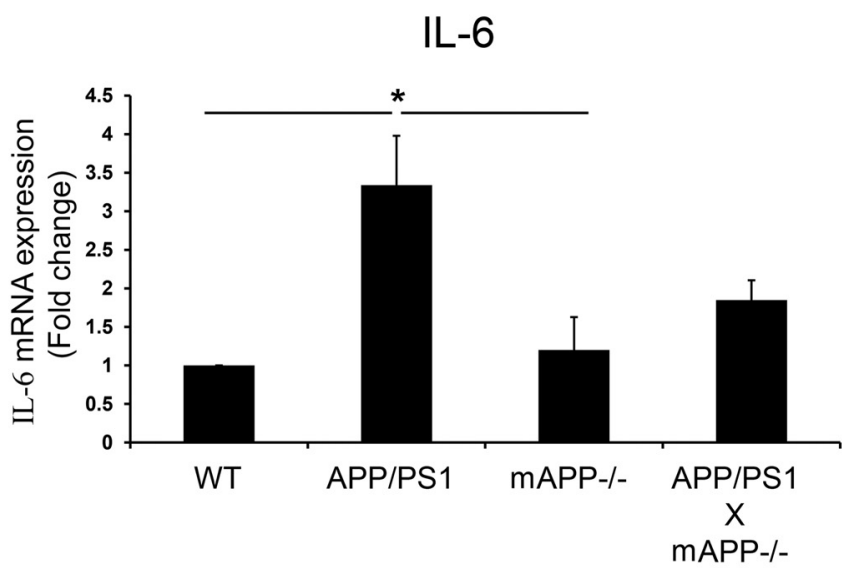

B

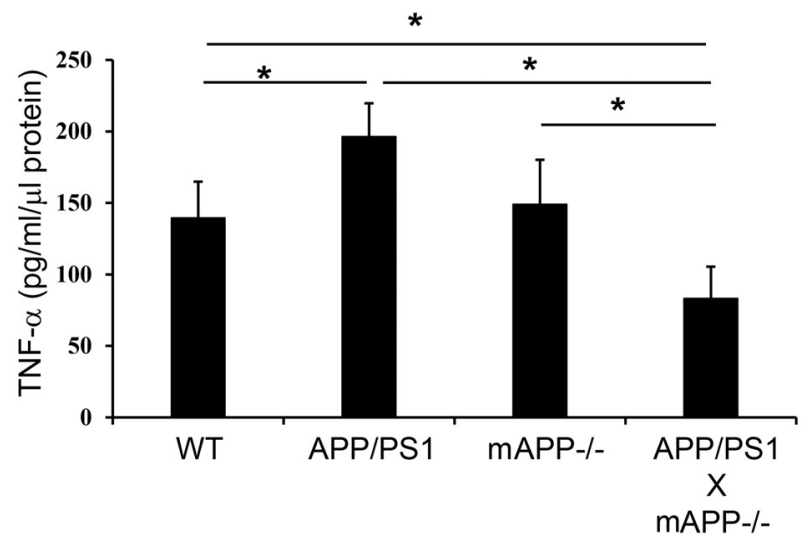

Figure 7. APP/PS1 $\times \mathrm{mAPP}^{-/-}$mice had attenuated TNF- $\alpha$ and IL-6 levels. Parietal cortices from left brain hemispheres from $6-7-\mathrm{month}-0 \mathrm{ld}$ C57BL/6 (WT) mice, APP/PS1 mice, mAPP -/- , and APP/PS1 $\times \mathrm{mAPP}^{-/-}$mice were collected for mRNA isolation and protein lysates. $\boldsymbol{A}, \boldsymbol{B}$, Levels of TNF- $\alpha, \mathrm{IL}-6$, and IL-10 mRNA $(\boldsymbol{A})$ and TNF- $\alpha$ protein levels $(\boldsymbol{B})$ were determined using real-time $P C R$ and ELISA, respectively. Fold change in the level of mRNA expression for each group was calculated as $2 \wedge-\Delta \Delta C_{t}$ with respect to average mRNA expression of the WT group. The values obtained for 3-8 animals per group were averaged and plotted ( \pm SEM; $\left.{ }^{*} p<0.05\right)$.

decreased anxiety compared with the APP/PS1 mice. Finally, to examine an $\mathrm{AD}$-relevant behavior, working memory was compared across the mouse lines by recording T-maze alternations. Although the APP/PS1 mice demonstrated the expected decrease in spontaneous alternations compared with WT mice, the APP/ PS $1 \times \mathrm{mAPP}^{-1-}$ mice did not (Fig. $8 A$ ). The behavioral comparisons demonstrated a correlation between our observed decrease of gliosis and cytokine expression in the brains of the APP/ $\mathrm{PS} 1 \times \mathrm{mAPP}^{-1-}$ mice and improved working memory, reduced anxiety, and increased exploratory behavior when compared with the parent APP/PS1 line.

\section{Discussion}

Our prior work demonstrated that APP can behave as a proinflammatory receptor on monocytic lineage cells mediating tyrosine kinase-based activation (Sondag and Combs, 2004). Therefore, we hypothesized that it may serve a similar function in microglia. Primary murine microglia cultures from WT and $\mathrm{mAPP}^{-1-}$ mice were stimulated with oligomeric or fibrillar $\mathrm{A} \beta$. Although fibrillar $\mathrm{A} \beta$ stimulated increased protein phosphotyrosine levels and $\mathrm{TNF} \alpha$ secretion from both cultures, oligomeric stimulation of $\mathrm{mAPP}^{-1-}$ microglia was significantly attenuated. In addition, $\mathrm{mAPP}^{-/-}$microglia cultures had no attenuation of phagocytic ability but demonstrated significant impairment in migratory ability in vitro compared with WT microglia. Similarly, intracerebroventricular infusions of oligomeric $\mathrm{A} \beta$ produced sig- nificantly less microgliosis in $\mathrm{mAPP}^{-1-}$ compared with WT mice. These findings suggested a role for APP in modulating the microglial response to selectively oligomeric $\mathrm{A} \beta$ and are consistent with our observation that $\mathrm{A} \beta$ oligomers bind to APP. We next crossed $\mathrm{mAPP}^{-/-}$mice with mice expressing human mutant APP/PS1 to assess whether absence of murine APP attenuated microgliosis in the presence of accumulations of $\mathrm{A} \beta$ oligomers and fibrils in vivo. The APP/PS1 $\times \mathrm{mAPP}^{-1-}$ mice had significantly reduced microgliosis despite similar plaque loads compared with APP/PS1 mice. This correlated with improved memory performance and decreased anxiety in the APP/ $\mathrm{PS} 1 \times \mathrm{mAPP}^{-1-}$ mice. These data define a novel function for microglial APP in regulating their migratory ability and response to $\mathrm{A} \beta$ peptides, which may be relevant for modulating their behavior in $\mathrm{AD}$.

We recognize that $\mathrm{A} \beta$ peptide may be secreted from a variety of cells, including neurons (Busciglio et al., 1993; Walsh et al., 2000; Takahashi et al., 2004), astrocytes (Siman et al., 1989; Haass et al., 1991), microglia (Banati et al., 1993b), or even peripheral cells for transport into the brain (Goldgaber et al., 1989; Farkas et al., 2003; Austin and Combs, 2010), where it may be responsible for the microglial activation associated with AD. Our data support the idea that APP may be able to generate its own ligand, oligomeric $\mathrm{A} \beta$, capable of regulating microglial phenotype in a paracrine or even autocrine fashion. This is further supported by 


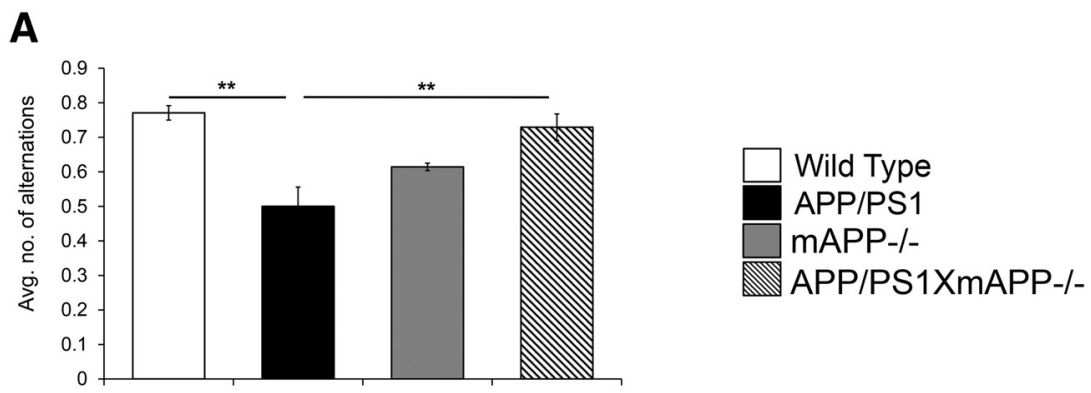

B
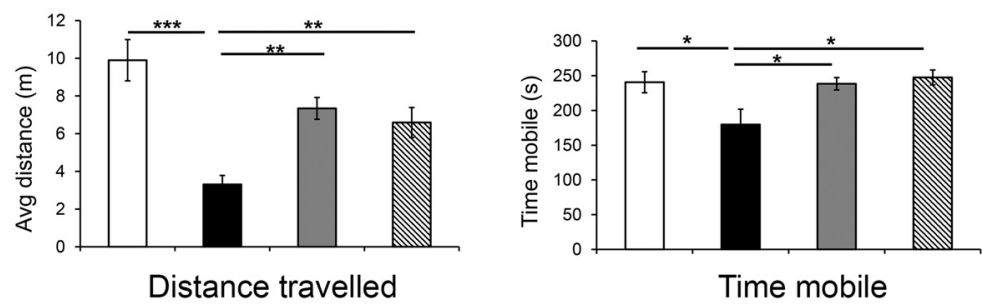

Time mobile

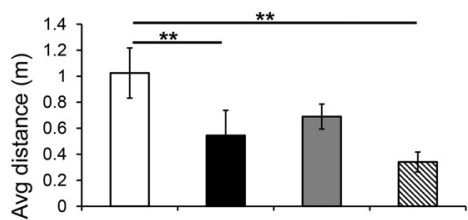

Center: distance

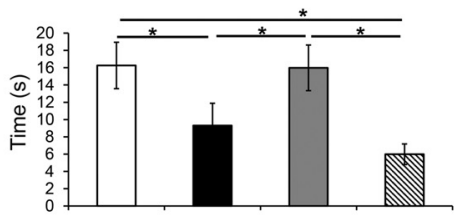

Center: Time

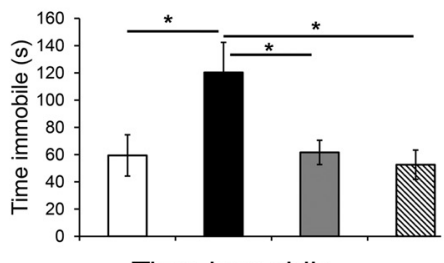

Time immobile

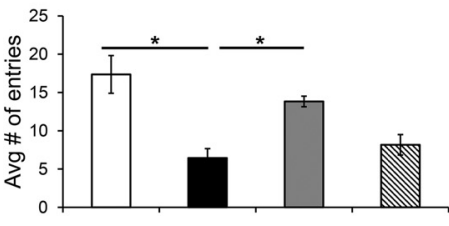

Q1: Entries

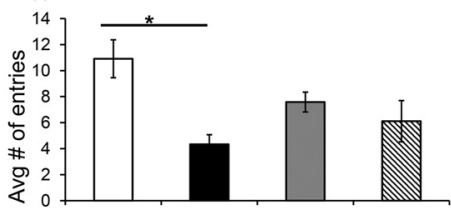

Q4: Entries

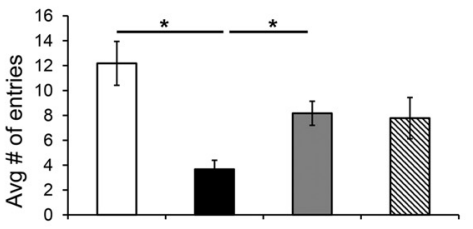

Q2: Entries

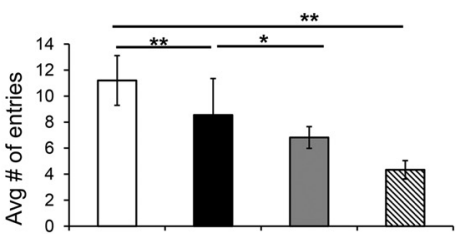

Center: Entries

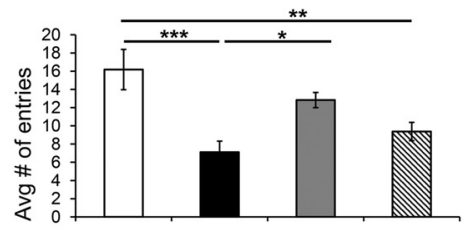

Q3: Entries

C

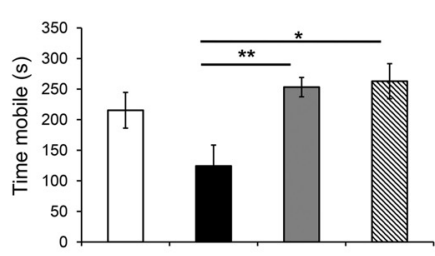

Time in Light

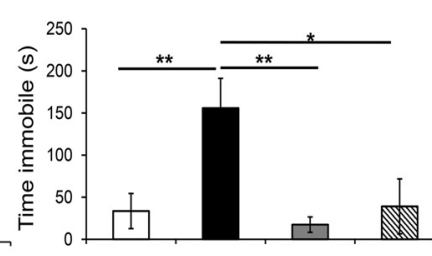

Light: Time immobile

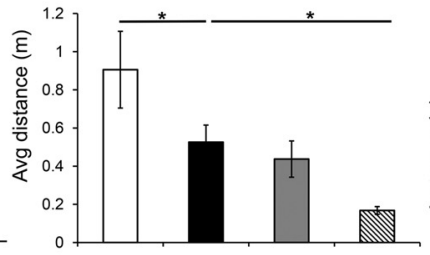

Distance travelled

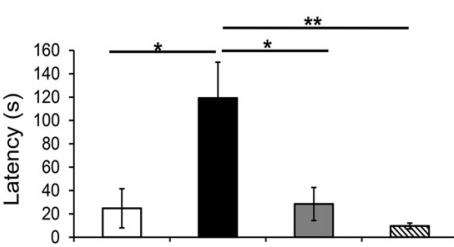

Dark: Latency to first entry

Figure 8. APP/PS1 $\times \mathrm{mAPP}^{-1-}$ mice had increased exploratory behavior, reduced anxiety, and improved working memory compared with APP/PS1 mice. $\boldsymbol{A}$, 10 -month-old (57BL/6 (WT), APP/PS1, mAPP ${ }^{-1-}$, and APP/PS1 $\times \mathrm{mAPP}^{-1-}$ mice $\left(n=10\right.$ per group) were subjected to T-maze testing and the number of alternations were recorded, averaged, and plotted ( \pm SD; ${ }^{*}<0.05$, ${ }^{* *} p<0.01,{ }^{* * *} p<0.001$ ). $\boldsymbol{B}$, In addition, the same mice were subjected to open-field testing. Total distance traveled, time mobile, and time immobile during the 5 min trial period was averaged (for $\geq 10$ mice per group) and plotted ( $\pm S D$ ). Total number of entries into the center zone, total time spent in the center zones, and the total distance traveled in the center zone were averaged and plotted ( \pm SD). Number of entries into each of the four quadrants $\left(01, Q 2, Q 3\right.$, and Q4) were noted, averaged, and plotted ( \pm SD; ${ }^{*} p<0.05$, $\left.{ }^{* *} p<0.01,{ }^{* * *} p<0.001\right)$. C, Finally, the mice were tested via light/dark box transitions for 5 min recording time spent in the light, time immobile in the light, distance traveled, and latency to first dark-side entry. The data were averaged $\left( \pm\right.$ SD; ${ }^{*} p<$ $0.05,{ }^{* *} p<0.01,{ }^{* * *} p<0.001$ ). 
our observations that oligomeric $\mathrm{A} \beta$ directly binds to APP with a very high affinity and this binding could be prevented by blocking the cell surface-expressed APP with anti-N-terminal APP antibodies. Our results correlate these specific APP binding sites on HEK293 GripTite cells with the physiological receptor on microglia because of the specific, saturable, and high-affinity binding properties of $\mathrm{A} \beta$ on these cells.

Although our in vitro data suggest that oligomeric $A \beta$ interacts directly with APP on microglia to stimulate a tyrosine kinasebased activation response, we appreciate that this may not be occurring in vivo. However, we showed via the acute intracerebroventricular infusion paradigm that APP expression was required for the oligomeric infusion to stimulate increased microglial activation in vivo. In addition, others have shown that oligomeric A $\beta$ both in vitro (Roher et al., 1996; Lue et al., 1999; McLean et al., 1999) and in vivo (Cleary et al., 2005; Klyubin et al., 2005; Lesné et al., 2006) stimulate microglial activation, which is at least consistent with the notion that this form of the peptide is a disease-relevant ligand. Nevertheless, we (Floden et al., 2005; Sondag et al., 2009; Dhawan and Combs, 2012; Dhawan et al., 2012) as well as many others (Banati et al., 1993a; Del Bo et al., 1995; Giulian et al., 1995; Klegeris et al., 1997; Combs et al., 1999, 2000, 2001a,b) have demonstrated robust microglial stimulation by fibrillar forms of $\mathrm{A} \beta$, suggesting that peptide-mediated activation in vivo could be temporally or spatially unique, depending upon what ligand the microglia are exposed to.

Although the infusion paradigm allowed us some ability to examine oligomeric $\mathrm{A} \beta$ as a stimulus, we are clearly not able to discern what form of peptide might be responsible for the microgliosis observed in the APP/PS1 mouse brains. However, even if some combination of peptide conformations or other stimuli in the brain are ultimately responsible for the microglial activation associated with these mice, reduced endogenous APP expression was sufficient to attenuate microglial activation. More importantly, this correlated with reduced cytokine mRNA levels and improved behavioral performance despite maintained overall plaque load, although the ratio of 1-40/1-42 may have been altered. This not only supported the idea that the inflammatory, gliotic changes in the brain contribute to cognitive dysfunction in disease but also that APP is an important modulator of microglial phenotype. We have previously reported a role for APP in modulating cell-cell adhesion, inflammatory response, and immune cell phenotype in monocytes, endothelial cells, and enteric immune systems (Sondag and Combs, 2004; Austin and Combs, 2010; Puig et al., 2012). Indeed, others have also demonstrated that APP immunoreactivity increases in microglia in rodent multiple sclerosis models (Gehrmann et al., 1995; Ferguson et al., 1997; Bitsch et al., 2000) or after traumatic brain injury (Sherriff et al., 1994; Bramlett et al., 1997; Thornton et al., 2006; Corrigan et al., 2011), suggesting that the protein does have a role in modulating the phenotype of these cells. We appreciate that loss of rodent $A \beta$ in parallel with loss of APP and other proteolytic fragments may also have contributed to the changes we observed. Indeed, although increased rodent $\mathrm{A} \beta$ production does not appear to promote plaque deposition or gliosis, it has been reported to alter human $\mathrm{A} \beta$ solubility and localization in transgenic mice (Jankowsky et al., 2007). Even though the specific mechanisms by which APP or any of its multiple metabolites regulate microglial activation in $\mathrm{AD}$ has not yet been resolved in either our study or prior work, further dissection of the role of APP in these immune cells will help define this. Indeed, prior work from other groups supports the idea that APP has a critical role in regulating overall immune phenotype (Grant et al., 2012; Kurnellas et al., 2014,
2015; Steinman et al., 2014). Perhaps most relevant to the current study is a recent publication by Carrano and Das (2015) demonstrating that APP knock-out microglia have attenuated cytokine secretion and altered morphologic phenotype both in vitro and in vivo in response to stimulation with LPS. This demonstrates that the role of APP in regulating microglial phenotype is likely much more complex than serving as a putative receptor for $\mathrm{A} \beta$ interaction.

Although the focus of this study has been on microglial $\mathrm{A} \beta$ APP interaction, it is clear that multiple causes of microgliosis may be relevant to AD and that APP is expressed by other cell types in the brain. Even though the infusion data better supports a role for APP in microgliosis with respect to specific oligomeric $\mathrm{A} \beta$ stimulation, the mice used in those experiments as well as in our APP/PS1 $\times \mathrm{mAPP}^{-1-}$ line lacked APP in all cell types. Therefore, in the absence of a cell-specific APP deletion, we at this stage interpret our findings to demonstrate that endogenous APP is needed for robust microgliosis, behavioral, and cytokine changes in the APP/PS1 mice. It is interesting to speculate that oligomeric $\mathrm{A} \beta$ may also be able to interact with APP expressed on neurons and astrocytes to mediate, for example, specific cellular responses concomitant with any stimulation of microglia. Future effort in this regard as well as cell-specific APP knockdown will better resolve which cell types require APP expression in order for the brain to mount the robust inflammatory, degenerative, and behavioral changes associated with $\mathrm{AD}$.

\section{References}

Akaaboune M, Allinquant B, Farza H, Roy K, Magoul R, Fiszman M, Festoff BW, Hantaï D (2000) Developmental regulation of amyloid precursor protein at the neuromuscular junction in mouse skeletal muscle. Mol Cell Neurosci 15:355-367. CrossRef Medline

Austin SA, Combs CK (2010) Amyloid precursor protein mediates monocyte adhesion in $\mathrm{AD}$ tissue and $\operatorname{apoE}(-) /(-)$ mice. Neurobiol Aging 31:1854-1866. CrossRef Medline

Austin SA, Sens MA, Combs CK (2009) Amyloid precursor protein mediates a tyrosine kinase-dependent activation response in endothelial cells. J Neurosci 29:14451-14462. CrossRef Medline

Banati RB, Gehrmann J, Schubert P, Kreutzberg GW (1993a) Cytotoxicity of microglia. Glia 7:111-118. CrossRef Medline

Banati RB, Gehrmann J, Czech C, Mönning U, Jones LL, König G, Beyreuther K, Kreutzberg GW (1993b) Early and rapid de novo synthesis of Alzheimer beta A4-amyloid precursor protein (APP) in activated microglia. Glia 9:199-210. CrossRef Medline

Bauer J, König G, Strauss S, Jonas U, Ganter U, Weidemann A, Mönning U, Masters CL, Volk B, Berger M (1991) In-vitro matured human macrophages express Alzheimer's beta A4-amyloid precursor protein indicating synthesis in microglial cells. FEBS Lett 282:335-340. CrossRef Medline

Beher D, Hesse L, Masters CL, Multhaup G (1996) Regulation of amyloid protein precursor (APP) binding to collagen and mapping of the binding sites on APP and collagen type I. J Biol Chem 271:1613-1620. CrossRef Medline

Bitsch A, Schuchardt J, Bunkowski S, Kuhlmann T, Brück W (2000) Acute axonal injury in multiple sclerosis. Correlation with demyelination and inflammation. Brain 123:1174-1183. CrossRef Medline

Borg JP, Ooi J, Levy E, Margolis B (1996) The phosphotyrosine interaction domains of X11 and FE65 bind to distinct sites on the YENPTY motif of amyloid precursor protein. Mol Cell Biol 16:6229-6241. CrossRef Medline

Bradford MM (1976) A rapid and sensitive method for the quantitation of microgram quantities of protein utilizing the principle of protein-dye binding. Anal Biochem 72:248-254. CrossRef Medline

Bramlett HM, Kraydieh S, Green EJ, Dietrich WD (1997) Temporal and regional patterns of axonal damage following traumatic brain injury: a beta-amyloid precursor protein immunocytochemical study in rats. J Neuropathol Exp Neurol 56:1132-1141. CrossRef Medline

Bullido MJ, Muñoz-Fernandez MA, Recuero M, Fresno M, Valdivieso F (1996) Alzheimer's amyloid precursor protein is expressed on the surface 
of hematopoietic cells upon activation. Biochim Biophys Acta 1313: 54-62. CrossRef Medline

Busciglio J, Gabuzda DH, Matsudaira P, Yankner BA (1993) Generation of beta-amyloid in the secretory pathway in neuronal and nonneuronal cells. Proc Natl Acad Sci U S A 90:2092-2096. CrossRef Medline

Cain JT, Berosik MA, Snyder SD, Crawford NF, Nour SI, Schaubhut GJ, Darland DC (2014) Shifts in the vascular endothelial growth factor isoforms result in transcriptome changes correlated with early neural stem cell proliferation and differentiation in mouse forebrain. Dev Neurobiol 74:63-81. CrossRef Medline

Carrano A, Das P (2015) Altered innate immune and glial cell responses to inflammatory stimuli in amyloid precursor protein knockout mice. PLoS One 10:e0140210. CrossRef Medline

Cheng Y, Prusoff WH (1973) Relationship between the inhibition constant (K1) and the concentration of inhibitor which causes 50 per cent inhibition (I50) of an enzymatic reaction. Biochem Pharmacol 22:3099-3108. CrossRef Medline

Chromy BA, Nowak RJ, Lambert MP, Viola KL, Chang L, Velasco PT, Jones BW, Fernandez SJ, Lacor PN, Horowitz P, Finch CE, Krafft GA, Klein WL (2003) Self-assembly of Abeta(1-42) into globular neurotoxins. Biochemistry 42:12749-12760. CrossRef Medline

Chung H, Brazil MI, Soe TT, Maxfield FR (1999) Uptake, degradation, and release of fibrillar and soluble forms of Alzheimer's amyloid beta-peptide by microglial cells. J Biol Chem 274:32301-32308. CrossRef Medline

Cleary JP, Walsh DM, Hofmeister JJ, Shankar GM, Kuskowski MA, Selkoe DJ, Ashe KH (2005) Natural oligomers of the amyloid-beta protein specifically disrupt cognitive function. Nat Neurosci 8:79-84. CrossRef Medline

Combs CK (2009) Inflammation and microglia actions in Alzheimer's disease. J Neuroimmune Pharmacol 4:380-388. CrossRef Medline

Combs CK, Johnson DE, Cannady SB, Lehman TM, Landreth GE (1999) Identification of microglial signal transduction pathways mediating a neurotoxic response to amyloidogenic fragments of $\beta$-amyloid and prion proteins. J Neurosci 19:928-939. Medline

Combs CK, Johnson DE, Karlo JC, Cannady SB, Landreth GE (2000) Inflammatory mechanisms in Alzheimer's disease: inhibition of $\beta$-amyloidstimulated proinflammatory responses and neurotoxicity by PPAR $\gamma$ agonists. J Neurosci 20:558-567. Medline

Combs CK, Karlo JC, Kao SC, Landreth GE (2001a) $\beta$-Amyloid stimulation of microglia and monocytes results in TNF $\alpha$-dependent expression of inducible nitric oxide synthase and neuronal apoptosis. J Neurosci 21: 1179-1188. Medline

Combs CK, Bates P, Karlo JC, Landreth GE (2001b) Regulation of beta-amyloid stimulated proinflammatory responses by peroxisome proliferator-activated receptor alpha. Neurochem Int 39:449-457. CrossRef Medline

Corrigan F, Pham CL, Vink R, Blumbergs PC, Masters CL, van den Heuvel C, Cappai R (2011) The neuroprotective domains of the amyloid precursor protein, in traumatic brain injury, are located in the two growth factor domains. Brain Res 1378:137-143. CrossRef Medline

Del Bo R, Angeretti N, Lucca E, De Simoni MG, Forloni G (1995) Reciprocal control of inflammatory cytokines, IL-1 and IL-6, and beta-amyloid production in cultures. Neurosci Lett 188:70-74. CrossRef Medline

Dhawan G, Combs CK (2012) Inhibition of Src kinase activity attenuates amyloid associated microgliosis in a murine model of Alzheimer's disease. J Neuroinflammation 9:117. CrossRef Medline

Dhawan G, Floden AM, Combs CK (2012) Amyloid-beta oligomers stimulate microglia through a tyrosine kinase dependent mechanism. Neurobiol Aging 33:2247-2261. CrossRef Medline

Esch FS, Keim PS, Beattie EC, Blacher RW, Culwell AR, Oltersdorf T, McClure D, Ward PJ (1990) Cleavage of amyloid beta peptide during constitutive processing of its precursor. Science 248:1122-1124. CrossRef Medline

Farkas IG, Czigner A, Farkas E, Dobó E, Soós K, Penke B, Endrész V, Mihály A (2003) Beta-amyloid peptide-induced blood-brain barrier disruption facilitates T-cell entry into the rat brain. Acta Histochem 105:115-125. CrossRef Medline

Ferguson B, Matyszak MK, Esiri MM, Perry VH (1997) Axonal damage in acute multiple sclerosis lesions. Brain 120:393-399. CrossRef Medline

Floden AM, Li S, Combs CK (2005) $\beta$-Amyloid-stimulated microglia induce neuron death via synergistic stimulation of tumor necrosis factor $\alpha$ and NMDA receptors. J Neurosci 25:2566-2575. CrossRef Medline

Galloway S, Jian L, Johnsen R, Chew S, Mamo JC (2007) beta-amyloid or its precursor protein is found in epithelial cells of the small intestine and is stimulated by high-fat feeding. J Nutr Biochem 18:279-284. CrossRef Medline

Gehrmann J, Banati RB, Cuzner ML, Kreutzberg GW, Newcombe J (1995) Amyloid precursor protein (APP) expression in multiple sclerosis lesions. Glia 15:141-151. CrossRef Medline

Giulian D, Haverkamp LJ, Li J, Karshin WL, Yu J, Tom D, Li X, Kirkpatrick JB (1995) Senile plaques stimulate microglia to release a neurotoxin found in Alzheimer brain. Neurochem Int 27:119-137. CrossRef Medline

Glenner GG, Wong CW (1984) Alzheimer's disease: initial report of the purification and characterization of a novel cerebrovascular amyloid protein. Biochem Biophys Res Commun 120:885-890. CrossRef Medline

Goldgaber D, Harris HW, Hla T, Maciag T, Donnelly RJ, Jacobsen JS, Vitek MP, Gajdusek DC (1989) Interleukin 1 regulates synthesis of amyloid beta-protein precursor mRNA in human endothelial cells. Proc Natl Acad Sci U S A 86:7606-7610. CrossRef Medline

Grant JL, Ghosn EE, Axtell RC, Herges K, Kuipers HF, Woodling NS, Andreasson K, Herzenberg LA, Herzenberg LA, Steinman L (2012) Reversal of paralysis and reduced inflammation from peripheral administration of beta-amyloid in TH1 and TH17 versions of experimental autoimmune encephalomyelitis. Sci Transl Med 4:145ra105. CrossRef Medline

Haass C, Selkoe DJ (1993) Cellular processing of beta-amyloid precursor protein and the genesis of amyloid beta-peptide. Cell 75:1039-1042. CrossRef Medline

Haass C, Hung AY, Selkoe DJ (1991) Processing of $\beta$-amyloid precursor protein in microglia and astrocytes favors an internal localization over constitutive secretion. J Neurosci 11:3783-3793. Medline

Haass C, Hung AY, Schlossmacher MG, Oltersdorf T, Teplow DB, Selkoe DJ (1993) Normal cellular processing of the beta-amyloid precursor protein results in the secretion of the amyloid beta peptide and related molecules. Ann N Y Acad Sci 695:109-116. CrossRef Medline

Herzog V, Kirfel G, Siemes C, Schmitz A (2004) Biological roles of APP in the epidermis. Eur J Cell Biol 83:613-624. CrossRef Medline

Jankowsky JL, Younkin LH, Gonzales V, Fadale DJ, Slunt HH, Lester HA, Younkin SG, Borchelt DR (2007) Rodent A beta modulates the solubility and distribution of amyloid deposits in transgenic mice. J Biol Chem 282:22707-22720. CrossRef Medline

Jarrett JT, Berger EP, Lansbury PT Jr (1993) The carboxy terminus of the beta amyloid protein is critical for the seeding of amyloid formation: implications for the pathogenesis of Alzheimer's disease. Biochemistry 32:4693-4697. CrossRef Medline

Joachim CL, Mori H, Selkoe DJ (1989) Amyloid beta-protein deposition in tissues other than brain in Alzheimer's disease. Nature 341:226-230. CrossRef Medline

Klegeris A, Walker DG, McGeer PL (1997) Interaction of Alzheimer betaamyloid peptide with the human monocytic cell line THP-1 results in a protein kinase C-dependent secretion of tumor necrosis factor-alpha. Brain Res 747:114-121. CrossRef Medline

Klyubin I, Walsh DM, Lemere CA, Cullen WK, Shankar GM, Betts V, Spooner ET, Jiang L, Anwyl R, Selkoe DJ, Rowan MJ (2005) Amyloid beta protein immunotherapy neutralizes Abeta oligomers that disrupt synaptic plasticity in vivo. Nat Med 11:556-561. CrossRef Medline

Kurnellas MP, Schartner JM, Fathman CG, Jagger A, Steinman L, Rothbard JB (2014) Mechanisms of action of therapeutic amyloidogenic hexapeptides in amelioration of inflammatory brain disease. J Exp Med 211: 1847-1856. CrossRef Medline

Kurnellas MP, Rothbard JB, Steinman L (2015) Self-assembling peptides form immune suppressive amyloid fibrils effective in autoimmune encephalomyelitis. Curr Top Behav Neurosci 26:221-232. CrossRef Medline

Lee YH, Tharp WG, Maple RL, Nair S, Permana PA, Pratley RE (2008) Amyloid precursor protein expression is upregulated in adipocytes in obesity. Obesity (Silver Spring) 16:1493-1500. CrossRef Medline

Lesné S, Koh MT, Kotilinek L, Kayed R, Glabe CG, Yang A, Gallagher M, Ashe $\mathrm{KH}$ (2006) A specific amyloid-beta protein assembly in the brain impairs memory. Nature 440:352-357. CrossRef Medline

Lorenzo A, Yuan M, Zhang Z, Paganetti PA, Sturchler-Pierrat C, Staufenbiel M, Mautino J, Vigo FS, Sommer B, Yankner BA (2000) Amyloid beta interacts with the amyloid precursor protein: a potential toxic mechanism in Alzheimer's disease. Nat Neurosci 3:460-464. CrossRef Medline

Lu DC, Shaked GM, Masliah E, Bredesen DE, Koo EH (2003) Amyloid beta protein toxicity mediated by the formation of amyloid-beta protein precursor complexes. Ann Neurol 54:781-789. CrossRef Medline

Lue LF, Kuo YM, Roher AE, Brachova L, Shen Y, Sue L, Beach T, Kurth JH, 
Rydel RE, Rogers J (1999) Soluble amyloid beta peptide concentration as a predictor of synaptic change in Alzheimer's disease. Am J Pathol 155:853-862. CrossRef Medline

Masters CL, Simms G, Weinman NA, Multhaup G, McDonald BL, Beyreuther K (1985) Amyloid plaque core protein in Alzheimer disease and Down syndrome. Proc Natl Acad Sci U S A 82:4245-4249. CrossRef Medline

McLean CA, Cherny RA, Fraser FW, Fuller SJ, Smith MJ, Beyreuther K, Bush AI, Masters CL (1999) Soluble pool of Abeta amyloid as a determinant of severity of neurodegeneration in Alzheimer's disease. Ann Neurol 46: 860-866. CrossRef Medline

Mönning U, König G, Banati RB, Mechler H, Czech C, Gehrmann J, Schreiter-Gasser U, Masters CL, Beyreuther K (1992) Alzheimer beta A4-amyloid protein precursor in immunocompetent cells. J Biol Chem 267:23950-23956. Medline

Perlmutter LS, Barron E, Chui HC (1990) Morphologic association between microglia and senile plaque amyloid in Alzheimer's disease. Neurosci Lett 119:32-36. CrossRef Medline

Puig KL, Floden AM, Adhikari R, Golovko MY, Combs CK (2012) Amyloid precursor protein and proinflammatory changes are regulated in brain and adipose tissue in a murine model of high fat diet-induced obesity. PLoS One 7:e30378. CrossRef Medline

Radde R, Bolmont T, Kaeser SA, Coomaraswamy J, Lindau D, Stoltze L, Calhoun ME, Jäggi F, Wolburg H, Gengler S, Haass C, Ghetti B, Czech C, Hölscher C, Mathews PM, Jucker M (2006) Abeta42-driven cerebral amyloidosis in transgenic mice reveals early and robust pathology. EMBO Rep 7:940-946. CrossRef Medline

Roher AE, Chaney MO, Kuo YM, Webster SD, Stine WB, Haverkamp LJ, Woods AS, Cotter RJ, Tuohy JM, Krafft GA, Bonnell BS, Emmerling MR (1996) Morphology and toxicity of Abeta-(1-42) dimer derived from neuritic and vascular amyloid deposits of Alzheimer's disease. J Biol Chem 271:20631-20635. CrossRef Medline

Rossjohn J, Cappai R, Feil SC, Henry A, McKinstry WJ, Galatis D, Hesse L, Multhaup G, Beyreuther K, Masters CL, Parker MW (1999) Crystal structure of the N-terminal, growth factor-like domain of Alzheimer amyloid precursor protein. Nat Struct Biol 6:327-331. CrossRef Medline

Sandbrink R, Masters CL, Beyreuther K (1994) Beta A4-amyloid protein precursor mRNA isoforms without exon 15 are ubiquitously expressed in rat tissues including brain, but not in neurons. J Biol Chem 269: 1510-1517. Medline

Selkoe DJ, Podlisny MB, Joachim CL, Vickers EA, Lee G, Fritz LC, Oltersdorf T (1988) Beta-amyloid precursor protein of Alzheimer disease occurs as 110- to 135-kilodalton membrane-associated proteins in neural and nonneural tissues. Proc Natl Acad Sci U S A 85:7341-7345. CrossRef Medline

Sharma S, Darland D, Lei S, Rakoczy S, Brown-Borg HM (2012) NMDA and kainate receptor expression, long-term potentiation, and neurogenesis in the hippocampus of long-lived Ames dwarf mice. Age (Dordr) 34: 609-620. CrossRef Medline

Sherriff FE, Bridges LR, Sivaloganathan S (1994) Early detection of axonal injury after human head trauma using immunocytochemistry for betaamyloid precursor protein. Acta Neuropathol 87:55-62. CrossRef Medline

Shoji M, Golde TE, Ghiso J, Cheung TT, Estus S, Shaffer LM, Cai XD, McKay DM, Tintner R, Frangione B (1992) Production of the Alzheimer amyloid beta protein by normal proteolytic processing. Science 258:126-129. CrossRef Medline

Siman R, Card JP, Nelson RB, Davis LG (1989) Expression of beta-amyloid precursor protein in reactive astrocytes following neuronal damage. Neuron 3:275-285. CrossRef Medline

Small DH, Nurcombe V, Moir R, Michaelson S, Monard D, Beyreuther K, Masters CL (1992) Association and release of the amyloid protein pre- cursor of Alzheimer's disease from chick brain extracellular matrix. J Neurosci 12:4143-4150. Medline

Soba P, Eggert S, Wagner K, Zentgraf H, Siehl K, Kreger S, Löwer A, Langer A, Merdes G, Paro R, Masters CL, Müller U, Kins S, Beyreuther K (2005) Homo- and heterodimerization of APP family members promotes intercellular adhesion. EMBO J 24:3624-3634. CrossRef Medline

Sondag CM, Combs CK (2004) Amyloid precursor protein mediates proinflammatory activation of monocytic lineage cells. J Biol Chem 279: 14456-14463. CrossRef Medline

Sondag CM, Combs CK (2010) Adhesion of monocytes to type I collagen stimulates an APP-dependent proinflammatory signaling response and release of Abeta1-40. J Neuroinflammation 7:22. CrossRef Medline

Sondag CM, Dhawan G, Combs CK (2009) Beta amyloid oligomers and fibrils stimulate differential activation of primary microglia. J Neuroinflammation 6:1. CrossRef Medline

Steinman L, Rothbard JB, Kurnellas MP (2014) Janus faces of amyloid proteins in neuroinflammation. J Clin Immunol 34 [Suppl 1]:S61-S63. CrossRef Medline

Takahashi RH, Almeida CG, Kearney PF, Yu F, Lin MT, Milner TA, Gouras GK (2004) Oligomerization of Alzheimer's $\beta$-amyloid within processes and synapses of cultured neurons and brain. J Neurosci 24:3592-3599. CrossRef Medline

Thornton E, Vink R, Blumbergs PC, Van Den Heuvel C (2006) Soluble amyloid precursor protein alpha reduces neuronal injury and improves functional outcome following diffuse traumatic brain injury in rats. Brain Res 1094:38-46. CrossRef Medline

Van Nostrand WE, Melchor JP, Keane DM, Saporito-Irwin SM, Romanov G, Davis J, Xu F (2002) Localization of a fibrillar amyloid betaprotein binding domain on its precursor. J Biol Chem 277:3639236398. CrossRef Medline

Vehmas A, Lieu J, Pardo CA, McArthur JC, Gartner S (2004) Amyloid precursor protein expression in circulating monocytes and brain macrophages from patients with HIV-associated cognitive impairment. J Neuroimmunol 157:99-110. CrossRef Medline

Wagner MR, Keane DM, Melchor JP, Auspaker KR, Van Nostrand WE (2000) Fibrillar amyloid beta-protein binds protease nexin-2/amyloid beta-protein precursor: stimulation of its inhibition of coagulation factor XIa. Biochemistry 39:7420-7427. CrossRef Medline

Walsh DM, Tseng BP, Rydel RE, Podlisny MB, Selkoe DJ (2000) The oligomerization of amyloid beta-protein begins intracellularly in cells derived from human brain. Biochemistry 39:10831-10839. CrossRef Medline

Walsh DM, Klyubin I, Fadeeva JV, Cullen WK, Anwyl R, Wolfe MS, Rowan MJ, Selkoe DJ (2002) Naturally secreted oligomers of amyloid beta protein potently inhibit hippocampal long-term potentiation in vivo. Nature 416:535-539. CrossRef Medline

Wenk GL (2001) Assessment of spatial memory using the T maze. Curr Protoc Neurosci Chapter 8:Unit 85B. CrossRef Medline

West MJ, Gundersen HJ (1990) Unbiased stereological estimation of the number of neurons in the human hippocampus. J Comp Neurol 296: 1-22. CrossRef Medline

Wisniewski HM, Wegiel J, Wang KC, Lach B (1992) Ultrastructural studies of the cells forming amyloid in the cortical vessel wall in Alzheimer's disease. Acta Neuropathol 84:117-127. CrossRef Medline

Yamada T, Sasaki H, Dohura K, Goto I, Sakaki Y (1989) Structure and expression of the alternatively spliced forms of mRNA for the mouse homolog of Alzheimer's disease amyloid beta protein precursor. Biochem Biophys Res Commun 158:906-912. CrossRef Medline

Young-Pearse TL, Bai J, Chang R, Zheng JB, LoTurco JJ, Selkoe DJ (2007) A critical function for $\beta$-amyloid precursor protein in neuronal migration revealed by in utero RNA interference. J Neurosci 27:14459-14469. CrossRef Medline 